\title{
大地震時における層中間ピン柱脚骨組の 連層柱による損傷分散効果と作用曲げモーメント評価

\author{
EFFECT OF MULTI-LAYER LEANING COLUMN ON DAMAGE CONCENTRATION MITIGATION OF \\ MULTI-STORY STEEL MOMENT RESISTING FRAMES WITH MID-STORY PIN COLUMN BASE SYSTEM
}

\author{
古川 幸*1, 田村直 樹*2，木村 祥 裕*3
}

\section{Sachi FURUKAWA, Naoki TAMURA and Yoshihiro KIMURA}

\begin{abstract}
Steel moment-resisting frames with mid-story pin column base system previously proposed to prevent the first story column yielding is seismically upgraded by a multi-layer leaning column. Effect on the prevention of story drift and stress concentration provided by an M. L. column is quantified with respect to its flexural stiffness by theoretical formulation, static and dynamic analysis of 3 to 9-stories frames. It is shown that seismic responses of the main frame are suitably predicted by theoretical formulation with Ai distribution, while external force distribution considering the second-order mode is proposed to predict flexural demand on the M. L. column.
\end{abstract}

Keywords : Steel Moment-Resisting Frame, Mid-story Pin Column Base System, Multi-layer leaning column, Beam Yielding Mechanism, Modified D-Value Method 鉄骨ラーメン骨組，層中間ピン柱脚機戜，連層柱，全層梁降伏型メカニズム，修正D値去

1. 序

\section{1 本研究の背景}

埋込み型柱脚や露出型柱脚を有する中低層鉄骨ラーメン骨組では, 保有水平耐力時における最下層柱脚の曲げ降伏は避け難く, 現行の 設計基準においても柱脚の曲げ降伏が許容されている ${ }^{1) 。 し か し, ~}$ 骨組の耐震設計において最も軸力比が大きい最下層の柱の曲げ降伏 を許容した場合，設計基準に準拠した骨組であっても，最下層柱が 降伏後, 早期に局部座屈を伴う耐力劣化を生じて, 最下層の崩壊を 招く可能性が指摘されている ${ }^{2)}$

そこで，鉄骨ラーメン骨組において，最下層柱の降伏を防ぎ全層 梁降伏メカニズムとなる構法として, 層中間ピン柱脚が提案された 3 7)。層中間ピン柱脚では，最下層中間で鉄骨柱柱脚と RC 柱をピン 接合し，最下層柱頭・柱脚の曲げ応力比を制御することで，骨組が 保有水平耐力に達寸るまで最下層柱の降伏を防ぐ設計が可能となる 3,4)。文献 7)では，層中間ピン柱脚を適用した鉄骨ラーメン骨組（層 中間ピン柱脚骨組と略する）の最下層を模した部分架構の水平力載 荷実験が行われ，提案する接合構法が十分にピンとみなせる力学性 状を有することが明らかにされている。さらに層間変形角が $0.05 \mathrm{rad}$ に達するまで上部鉄骨柱の弾性を保持し, 下部 RC 柱の損傷も防ぐ ことが示されている。文献 3,4)では，3,6,9層骨組の地震動を用いた 動的応答解析 $(\mathrm{PGV}=0.75 \mathrm{~m} / \mathrm{s})$ により, 層中間ピン柱脚骨組では, 柱梁耐力比 1.4 2.1 の範囲で幅厚比が FA, FB ランクのいずれの柱部 材を用いても柱の累積塑性変形倍率が部材の保有值を下回り，部材
崩壊が防げることが示された。一方で，柱梁耐力比が 1.8 であって も全層梁降伏メカニズム形成前の中間層柱頭降伏が免れないことも 示されている。

現行の設計基準に従って設計された中低層骨組であっても，地震 時に骨組に作用するせん断力が $\mathrm{Ai}$ 分布に沿うとは限らず，他層が 余力を残したまま特定の層に損傷が集中寸る可能性が指摘されてい る ${ }^{8)}$ 。そこで，他層への損傷分散効果を有する構造要素（=損傷分 散要素 $\left.{ }^{13)}\right)$ として, 全層に渡って連続させた弾性部材が着目されて いる ${ }^{915)}$ 。このうち, 特にラーメン構造を対象とした, 下端ピン支 持の損傷分散効果を有する構造要素を，本論文では総じて連層柱 (Multi-layer leaning column) と呼称する。連層柱の具体例として, ブレース構造における柱材 (弾性柱) 9 12)や, 梁降伏型ラーメン構造 における弾性を保つ柱材（配力柱） ${ }^{13)}$ ，下端ピン支持の連層耐震壁

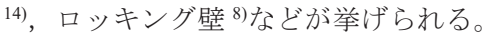

鉄骨ブレース構造における柱材の損傷分散効果を評価した一連の 研究 9 12)においては，ブレース座屈に伴う主架構の層剛性の劣化を 考慮し，十分な損傷分散効果が得られる柱材の曲 げ剛性や曲げ耐力 を明らかにしている ${ }^{12)}$ 。一方で, ラーメン構造を対象とする研究 ${ }^{13,14}$ においては，主架構の柱の曲げ降伏を考慮しているものの，柱部材 の塑性変形性能を検討対象としていない。文献 15)において, 連層柱 を付与した埋込み型柱脚を有する鉄骨ラーメン骨組では，連層柱が ない場合と同様に, 層間変形角 $0.01 \mathrm{rad}$ 未満で最下層柱脚が曲げ降 伏することが示されている。
*1 東北大学大学院工学研究科 助教 ·博士 (工学)

*2 東北大学大学院工学研究科 博士前期課程 - 学士 (工学)

*3 東北大学大学院工学研究科 教授・博士 (工学)
Assist. Prof., Graduate School of Eng., Tohoku University, Dr.Eng. Grad. Student, Graduate School of Eng., Tohoku University, B.Eng.

Prof., Graduate School of Eng., Tohoku University, Dr.Eng. 
また，鉄骨ブレース構造を対象とした研究 ${ }^{9-12}$ においては，静的 な釣合方程式を誘導して, 柱材による特定層への損傷集中抑制効果 および柱材に作用する曲げモーメントを理論的に評価している。一 方で, ラーメン構造を対象とした研究 ${ }^{14,15}$ においては, 動的応答解 析により, 主架構の水平剛性と連層柱の曲げ剛性を変数として, 主 架構の層間変形角や層せん断力, 連層柱に作用寸る曲げモーメント の分布性状を示したのみである。特に, 主架構および損傷分散要素 の動的解析結果は, 鉄骨ブレース構造に関する研究では静的な釣合 方程式と比較することで評価しているものの, 骨組の高次モード応 答の影響は明らかにはされていない 9 12)。さらに, 骨組の動的応答 特性と入力波の周期特性の関係を考慮し, 主架構および損傷分散要 素の動的応答特性を評価したものは見当たらない。

\section{2 本論文の目的}

本論文では，鉄骨ラーメン骨組を対象とし，保有水平耐力時に全 層梁降伏メカニズムの形成を可能とするため, 最下層柱脚の曲げ降 伏を防ぐ層中間ピン柱脚骨組 ${ }^{3 \sim 7}$ に, さらに損傷分散効果を有する連 層柱を付与する。本論文では, 骨組に付与した連層柱の曲げ剛性と 層中間ピン柱脚骨組の力学特性の関係, さらに連層柱作用曲げモー メントとの関係の定量的な評価法を提案する。評価法を用いること で，目標とする層中間ピン柱脚骨組の力学特性を実現するために必 要な連層柱曲げ岡性を合理的に選定できる。著者等はこれまでに, 層中間ピン柱脚骨組の水平外力に対して全層梁降伏メカニズムが形 成されるまでの各層梁降伏時の層せん断力と層間変形角関係やその ときの骨組の曲げモーメント分布を評価できる手法として, 修正 D 值法 ${ }^{16)}$ を提案している。修正 D 值法では, 骨組の層剛性や曲げモー メント分布を決定する各層反曲点高さは, 柱梁剛比, 梁剛比分布, 層高さ分布及び柱脚形式の影響項の単純和で求められる。骨組諸元 と骨組の力学特性の関係の定量的な評価式を提案することで, 目標 となる力学特性を満たす骨組諸元を合理的に設定できる。文献 5)で は，層中間ピン柱脚骨組の力学特性が魚骨形骨組モデルで精度よく

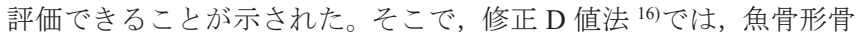
組を対象として水平外力に対する骨組の水平変形に関する釣合方程 式を構築している。

本論文では, 主架構である層中間ピン柱脚骨組の力学特性は修正 $\mathrm{D}$ 值法 ${ }^{16)}$ で評価し, 主架構と連層柱の水平外力に対する静的な力の 釣合方程式に基づき骨組全体の力学特性評価式を導く。評価式と静 的増分解析により, 保有水平耐力時に全層梁降伏メカニズム形成に 必要な連層柱の曲げ剛性と主架構の柱に必要な曲げ耐力の関係を明 らかにする。さらに, 連層柱を弾性に保つために必要な曲げ耐力を 示す。地震動を用いた動的応答解析により, 連層柱の作用曲げモー メントへの高次モード応答の影響を明らかにし, モード分解法に基 づく高次モード応答評価法を提案する。

\section{2. 連層柱を付与した層中間ピン柱脚骨組の水平外力に対する静的 な釣合方程式による力学特性評価法の提案}

図 1 に, 層中間ピン柱脚骨組に連層柱を付与した場合の (a)力学モ デルと(b)せん断力分布モデルを示す。ここで, $n$ は骨組の層数を示 し, 図 1 は $n=3$ の場合を例に示している。主架構である層中間ピン 柱脚骨組は, 文献 16) と同様に最下層層中間にピン接合を有する魚 骨形骨組としてモデル化する。文献 7)において, 保有水平耐力時に

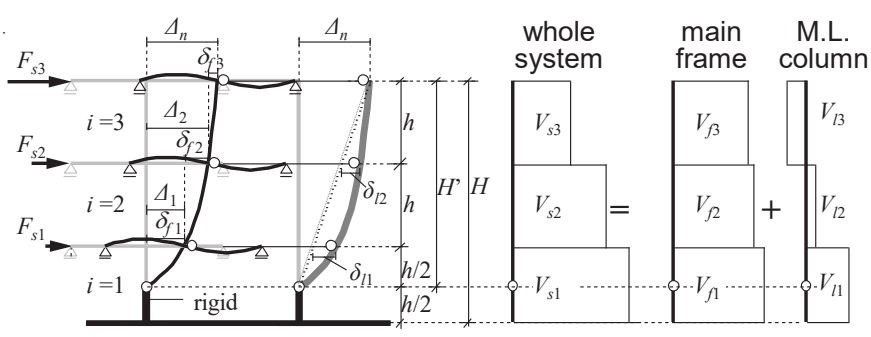

$\begin{array}{ll}\text { (a) External force and frame deformation } & \text { (b) Shear distribution }\end{array}$

Fig.1 Deformation and shear force distribution of fishbone frame with M.L. column subjected to lateral force $(n=3)$
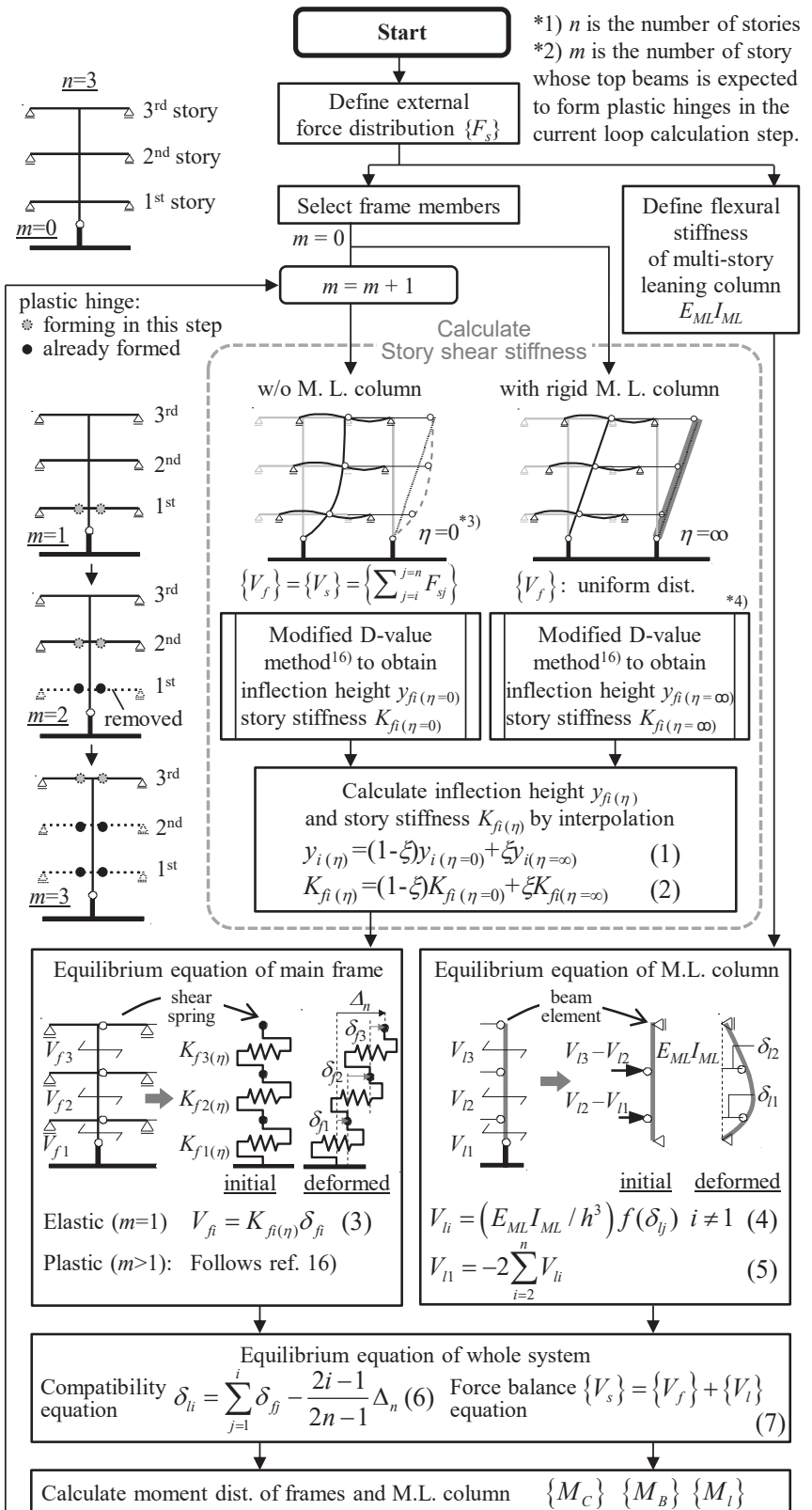

Calculate moment dist. of frames and M.L. column $\left\{M_{C}\right\}\left\{M_{B}\right\}\left\{M_{l}\right\}$

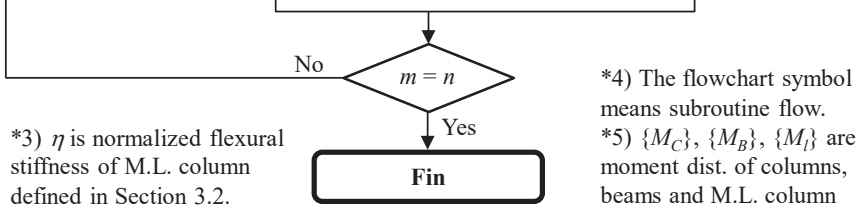

beams and M.L. column

Fig.2 Flowchart of theoretical formulation applied for fishbone steel moment-resisting frame with M. L. column $(n=3)$ 
おいても下部 RC 柱の損傷を最小限とする断面を採用することで, 下部 $\mathrm{RC}$ 柱の変形角は最下層層間変形角の $1 \%$ 未満に抑えられるこ とが確認された。そこで, ピン接合より下部の柱は剛としてモデル 化する ${ }^{16)}$ 。図 1 (a)中の $l_{B}, h, H$ は梁のスパン長, 層高さ, 骨組高さ である。ここでは, 層中間ピン柱脚の適用高さは $h / 2$ とする。主架 構各層梁の両端はピンローラー支持とする。連層柱は, 図 1(a)主架 構の右に示すように下端ピン支持の梁要素の線材としてモデル化し, 各階梁高さで繋ぎ梁を介して主架構に連結される。ここでつなぎ梁 は, 主架構と連層柱の間で層せん断力を伝達する働きを有し, 軸力 のタが作用する両端にピンを有する剛なトラス要素としてモデル化 する。連層柱は最下層中間にピン柱脚を有する主架構の変形を均一 化することを目的とするため, 連層柱下端のピン接合は, 主架構と 同高さとする。図 $1(\mathrm{a})$ 中の $\Delta_{n}$ は骨組頂部の水平变位, $\Delta_{i}$ は骨組 $i$ 層 の水平変位, $\delta_{f i}$ は骨組 $i$ 層の層間変位である。連層柱には, 連層柱 の下端ピン支持回りの剛体回転によって生じる水平変位から, さら にたわみが生じた時に応力が発生する。そこで, 連層柱の水平変位 $\delta_{l i}$ を, 連層柱の傾き $\left(=\Delta_{n} /(H-h / 2)\right)$ による $i$ 層の水平変位を基準と したときの, 連層柱 $i$ 層の水平たわみ量と定義する。ここで, 最下 層ピン接合高さから骨組頂部までの高さ $(H-h / 2)$ を $H^{\prime}$ とし， $\Delta_{n} / H^{\prime}$ を頂部変形角と定義する。水平外力 $\left\{F_{s}\right\}$ によって骨組全体に作用す るせん断力 $\left\{V_{s}\right\}$ は, 図 1 (b)に示すように主架構と連層柱にそれぞれ $\left\{V_{f}\right\}$ と\{ $\left.V_{l}\right\}$ として分配される。

図 2 に, 図 1 で示した力学モデルを用いて, 連層柱を付与した層 中間ピン柱脚骨組の主架構の層剛性, 骨組水平変位, せん断力 ・曲 げモーメント分布の算出フローを示寸。図 2 中のモデル図は 3 層骨 組 $(n=3)$ を例に示す。以上に列挙した骨組全体の力学特性は, 主架 構と連層柱のそれぞれにおいて各層での作用せん断力と層間変位の 釣合方程式（(1) (5)式）を導出し, 各階梁高さでの適合条件式 ((6) 式）と骨組全体に作用する水平外力との力の釣合方程式（(7)式）を 解くことで算出する。

主架構の層中間ピン柱脚骨組の力学特性は, 修正 D 值法 ${ }^{16)}$ により 算出する。修正 D 值法 ${ }^{16)}$ では, 下層から上層にかけて梁降伏が進展 するとし, 新たな層の梁が降伏するたびに各層の層剛性, 層せん断 力, 曲げモーメント, 層間変位を逐次計算する。ここで, 梁は完全 弾塑性とする。増分計算を行うことで, 梁降伏の進展に伴う主架構 層剛性の低下を考慮した主架構と連層柱間の応力再配分を考慮でき る。図 2 のフローチャートにおいて, $m$ は現在のループ計算におい て降伏を想定する梁の層数を示し, $m=1$ から $m=n$ (つまり全層梁 降伏の形成）となるまでループ計算を行う。

連層柱を鉄骨ラーメン骨組に付与させた場合, 主架構に作用する せん断力分布 $\left\{V_{f}\right\}$ は連層柱の曲渢性 $E_{M L} I_{M L}$ によって変化する。こ こで， $E_{M L}, I_{M L}$ はそれぞれ連層柱のヤング係数, 断面二次モーメン トである。ラーメン骨組の層剛性は柱曲げモーメント分布（せん断 力分布）に依存するため ${ }^{17}$, 各層層剛性を骨組全体の力の釣合方程 式から独立して定めることができない。そこで, 本論文では, 連層 柱を付与させた主架構の層剛性を算出するにあたり, 連層柱が十分 に柔な場合の層剛性 $K_{f i(\eta=0)}$ を下限, 連層柱が十分に剛な場合の層剛 性 $K_{f i(\eta=\infty)}$ を上限として, 内挿する方法を採用する（図 2, (2)式）。 ここで, (2)式で用いる内挿係数 $に$ ついては, 3.2 節で提案・評価す る。以上から，主架構における各層の釣合方程式（(3)式）を得る。
一方，連層柱の 2 層以上における釣合方程式は，仮想仕事法によっ て(4)式となる。第 1 層の釣合方程式は, 連層柱の下端ピン支持回り の回転力の釣合式 ((5)式) より算出する。なお，主架構の曲げモー メント分布の反曲点高さ比 $y_{i}$ は, 層剛性と同様に, 連層柱の曲げ剛 性比に関して内挿する (図 2,(1)式)。ここで，(1),(2)式の連層柱が十 分に剛な場合の主架構の反曲点高さ比 $y_{i(\eta=\infty)}$ と層剛性 $K_{f i(\eta=\infty)}$ は, 主架構の層せん断力 $V_{f i}$ が均一分布であると仮定して修正 D 值法 ${ }^{16)}$ を用いて算出する。

(3)式と(4)，(5)式を，(6)式に示される各階梁高さでの適合条件式 (図 1(a)）と(7)式に示される骨組全体に作用寸る外力との力の釣合 方程式（図 1(b)）について解くことで, 骨組全体の力学特性を算出 する。付録 1 に，(3) (7)式より得られる釣合方程式を，3 層骨組を 例に説明する。

\section{3. 静的地震外力を受ける連層柱を付与した層中間ピン柱脚骨組の 層間変形角・曲げモーメント集中抑制効果}

連層柱を付与した層中間ピン柱脚骨組に水平外力を作用させた場 合の力学特性を, 静的増分解析と 2 章で提案した静的な釣合方程式 により評価する。なお，層中間ピン柱脚骨組は現行の設計基準に従 つて設計された骨組 ${ }^{3)}$ とする。検討対象とするのは, 文献 16) と同様 に $3,6,9$ 層骨組とする。

\section{1 静的増分解析概要}

図 3 に連層柱を付与した層中間ピン柱脚を有する魚骨形骨組の数 值解析モデルとして，6 層を例に示す。数值解析モデルは図 1(a)に 示した力学モデルに基づく。数值解析プログラムは OpenSees 3.0.3を 用いた。魚骨形骨組の 1 層あたりの重量 $w_{i}$ を $615 \mathrm{kN}^{5}$ とする。最下 層の梁と柱断面の組み合わせは, 塑性断面係数比で 1.8 に相当する。 表 1 に柱及び梁断面を示す。3 層骨組では第 3 層で, 6,9 層骨組では 3 層ごとに部材断面を切り替えた。ここで, 切り替えた層の柱梁曲 げ剛性比 ${ }^{17)}$ の直下の層に対する比率 $\alpha_{j}$ は文献 3),16)で用いた骨組を 参考にして, 3 層骨組では 0.75, 6 層, 9 層骨組では 0.85 とする。柱 と梁は梁要素としてモデル化し, 鋼材の応力-歪関係は完全弾塑性と する。鋼材の材料特性を表 2 に示す。剛床仮定を適用し，各層の柱 梁接合部と左右の梁端の水平変位は等しいものとする。本論文では, 骨組柱及び連層柱に作用寸る曲げモーメントを明らかにするため, 柱及び連層柱を弾性とする。外力分布は $\mathrm{Ai}$ 分布に基づく。

Table 1 Section of components
(Unit: mm)



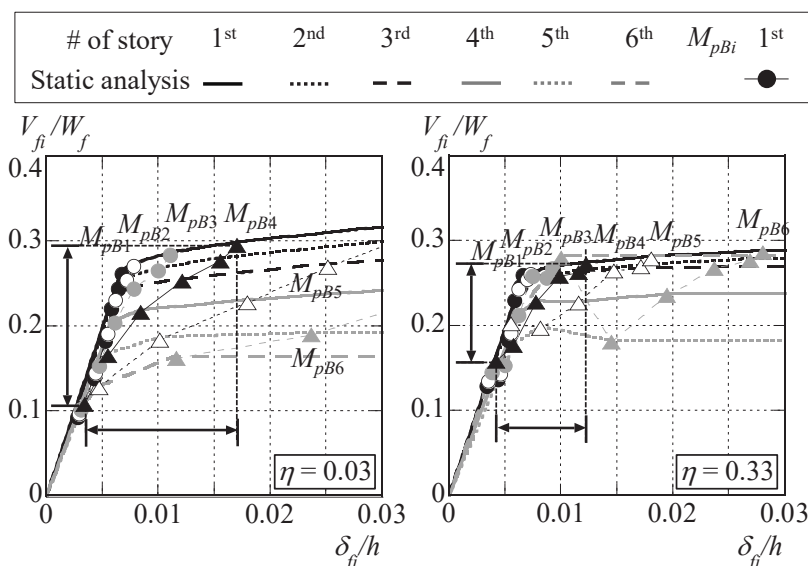

Fig.4 Relationship between shear force of main frame and

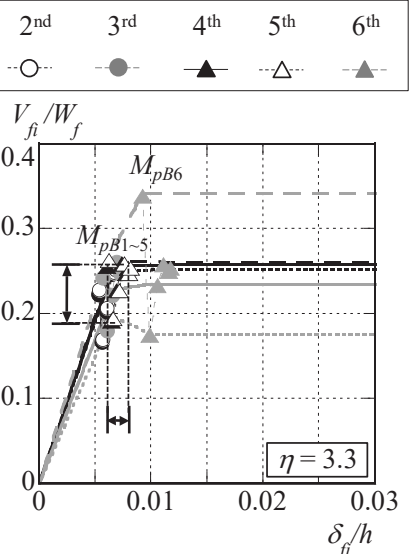

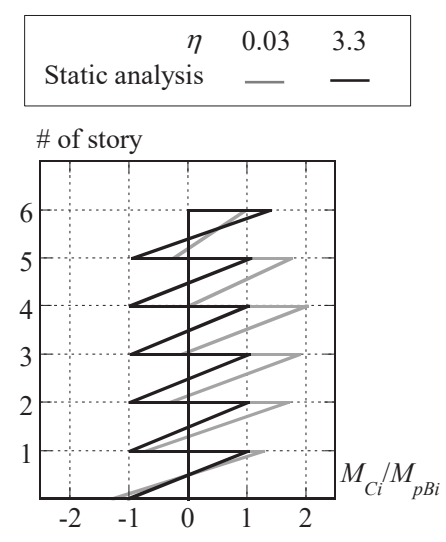

Fig. 5 Column moment distribution at $M_{p B 5}$ (6-story frame)
連層柱曲げ剛性が主架構の力学特性に及ぼす影響を表す指標とし て, 連層柱曲げ剛性比 $\eta$ を主架構の水平剛性を基準として(8)式で定 義する。ここで, 主架構の水平剛性として第 1 層柱の曲げ岡性 $E_{C} I_{C 1}$ を用いる。なお, 多スパンの骨組を対象とする場合, (8)式分母の $E_{C} I_{C 1}$ は骨組第 1 層を構成する全ての柱の曲げ剛性の総和 $\Sigma E_{C} I_{C 1}$ となる。 多層骨組では同一の $E_{M L} I_{M L}$ に対して連層柱のたわみ角がより大きく なることを考慮し， $E_{M L} I_{M L}$ と $E_{C} I_{C 1}$ の比を $H / h$ で除した。

$$
\eta=\frac{E_{M L} I_{M L}}{E_{C} I_{C 1}} / \frac{H}{h}
$$

\section{2 静的増分解析による連層柱の曲げ剛性と層間変形角・曲げモ ーメント集中抑制効果の関係}

図 4 に, 6 層骨組における各層作用せん断力と層間変形角 $\delta_{f i} / h$ の 関係を示す。縦軸は主架構全重量 $W_{f}$ で基準化した主架構の各層作用 せん断力 $V_{f i} / W_{f}$ である。横軸は層間変形角 $\delta_{f} / h$ である。図 4 中のプ ロットは, 各層梁全塑性降伏時 (各層 $M_{p B i}$ 時) における各層作用せ 几断力 $V_{f i} / W_{f}$ と層間変形角 $\delta_{f} / h$ を示す。図 4 には $M_{p B 4}$ 時における $V_{f i}$ $/ W_{f}$ と $\delta_{f} / h$ のばらつきの範囲を示寸補助線も追加した。図 4 より, 連 層柱曲げ剛性比 $\eta=0.03$ では, 各層梁降伏時（図 4 中 $M_{p B i}$ のプロッ 卜）における主架構の層間変形角 $\delta_{f i} / h$ と層せん断力 $V_{f i} / W_{f}$ のばらつ きは大きい。 $M_{p B 4}$ 時の層間変形角と層せん断力の最大值は, それぞ れ最小值の 5.36 倍と 2.71 倍となった。 $\eta=3.3$ では $M_{p B 5}$ 時まで, 各 層梁降伏時における主架構の各層層間変形角と層せん断力の最大值 が, それぞれ最小值の 1.31 倍と 1.18 倍となり, 全層均一に近づく傾 向を示した。その結果, $\delta_{f i} / h=0.006 \sim 0.008 \mathrm{rad}$ の範囲で 1 5 層の梁
がほぼ同時に塑性化する。なお， $\eta=3.3$ においても $M_{p B 5}$ 時以降で層 せん断力のばらつきが大きくなる点については, 後述する。

図 5 に，6 層骨組における $M_{p B 5}$ 時の主架構の柱曲げモーメント分 布を示す。横軸の主架構の柱曲げモーメント分布は, 当該層の梁の 全塑性曲げモーメント $M_{p B i}$ で基準化している。層中間ピン柱脚骨組 では下層の梁が塑性化すると, 反曲点が下降し, 上層の柱頭作用曲

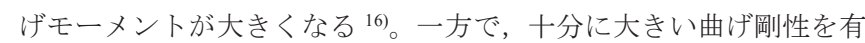
する連層柱を付与した場合, 主架構の全層層間変形角が均一化する ため (図 $5, \eta=3.3$ ), 各層曲げモーメント分布の反曲点が層中央へと 移動し, 柱頭, 柱脚の作用曲げモーメントがより等しくなる。

なお，図 4 の $\eta=3.3$ では，全層梁降伏時（図 4 中、）に最上層（第 6 層) の作用せん断力が下層より顕著に大きくなる現象がみられる。

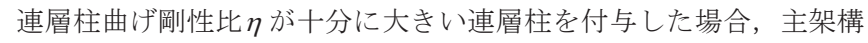
の層間変形角が強制的に均一になる。その結果, 各層梁高さで主架 構からの反力を受けた連層柱の上部の支点反力が最上層に作用する ため, 最上層のせん断力は大きくなる傾向にある。また, 上述の通 り，柱の曲げモーメントの反曲点が層中央へと移動する。一方で, 最上層の柱頭は梁の 2 倍の曲げモーメントを負担する。従って, 全 層梁降伏時では最上層のせん断力が 5 層以下に比べて増加する傾向 にある。

図 6 に連層柱曲げ剛性比 $\eta$ に対する, 頂部変形角 $\Delta_{n} / H^{\prime}=0.01,0.02$, $0.03 \mathrm{rad}$ 時の(a)層間変形集中率 $\gamma, \quad(\mathrm{b})$ 主架構の柱に作用寸る最大曲 げ モーメント $M_{\text {Ctimax }}$, (c)連層柱の最大曲げモーメント $M_{\text {lmax }}$ を 3,6,9 層 骨組について示す。(b)は当該層の梁の全塑性曲げモーメント $M_{p B i}$,

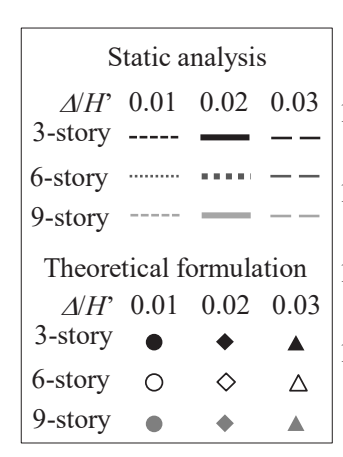

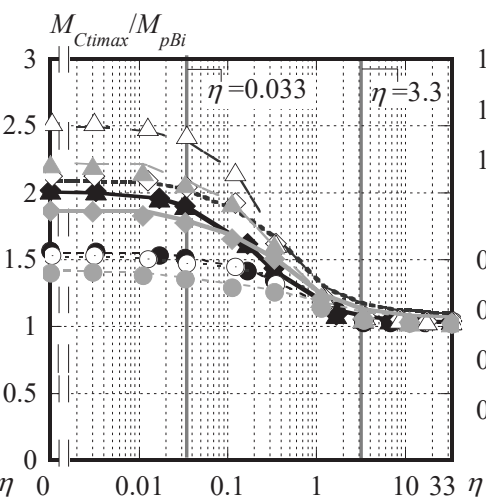

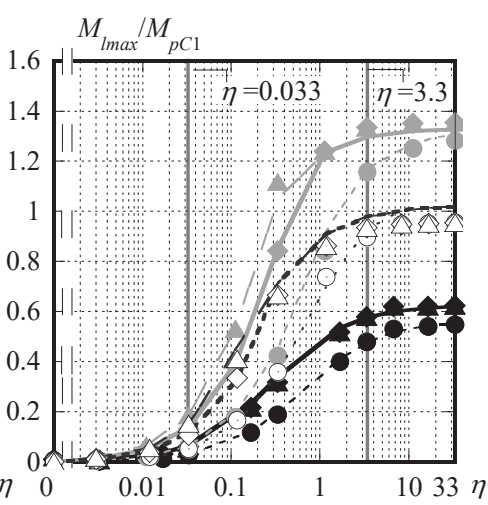

$\begin{array}{llll}\text { (a) concentration rate of interlayer deformation (b) maximum moment of the column top } & \text { (c) maximum moment of M.L. column }\end{array}$ Fig.6 Structural mechanical characteristics with respect to flexural stiffness ratio of M.L. column 
(c)は最下層柱の全塑性曲げモーメント $M_{p C 1}$ で, それぞれ基準化して いる。横軸の連層柱曲げ剛性比 $\eta$ は $\log$ スケールで示す。図中のプロ ットは 2 章の評価法による結果である。詳細は次節で説明する。な お, (a)の層間変形集中率 $\gamma$ は, $\Delta_{n} / H^{\prime}=0.01,0.02,0.03 \mathrm{rad}$ 時に最大とな る層の層間変形角を頂部変形角で除したものである。(a) (c)に示寸 各力学特性は, 連層柱が無い場合 $(\eta=0)$ と連層柱が十分に剛な場 合 $(\eta \approx 30)$ である場合に近づくに従って一定の值に収束する。 $\eta=0.03$ 程度以下では連層柱の効果は見られず, $\eta=3.3$ を超えると連層柱が 十分に剛な場合とおお屯祆同様となる。6 層骨組においては,

(a) $\Delta_{n} / H^{\prime}=0.02 \mathrm{rad}$ 時の層間変形集中率 $\gamma$ は, $\eta=0.03$ では $1.7, \eta=0.33$ で は $1.4, \eta=3.3$ ではほぼ 1 となる。同様に(b) $\Delta_{n} / H^{\prime}=0.02 \mathrm{rad}$ 時の主架 構の柱に作用する最大曲げモーメント $M_{C t i m a x} / M_{p B i}$ は, $\eta=0.03$ では 2.1, $\eta=0.33$ では $1.6, \eta=3.3$ ではほぼ 1 となる。一方で, (c) $\Delta_{n} / H^{\prime}=0.02 \mathrm{rad}$ 時の連層柱最大曲げモーメント $M_{l \max } / M_{p C 1}$ は, $\eta=0.33$ で $0.7, \eta=3.3$ で 1.0 となる。

以上から, 連層柱曲げ岡性比 $\eta=3.3$ では主架構の層間変形角や作 用曲げモーメントが全層に渡って均一となる効果が得られ, 連層柱 曲げ岡性比 $\eta=0.33$ では層間変形集中率および曲げモーメントを十 分に剛な場合の半分程度まで抑制する効果が得られる。

\section{3 静的な釣合方程式による評価と静的増分解析結果の比較}

前節の図 6 より, 連層柱を付与した層中間ピン柱脚骨組の力学特 性は, $\eta=0.03$ 程度以下では連層柱がない場合の層中間ピン柱脚骨組 と同様な挙動を示し, $\eta=3.3$ 以上では連層柱が十分に剛な場合と同 様な挙動を示した。また, $\eta=0.03$ と $\eta=3.3$ 程度の間では, 各力学特 性は連層柱の曲げ剛性比 $\eta$ に対して $\log$ スケール上で直線的な変化 を示す。そこで, $\eta=0.03$ と $\eta=3.3$ の間の連層柱曲げ岡性を有する場 合, (9)式で定義される内挿係数 $\xi$ 用いて, 主架構の層剛性と反曲点高 さ比（図 2 中(1),(2)式）を算出する。

$$
\xi=\frac{\log 3 \eta+1}{2}
$$

(9)式を用いた 2 章の評価法による算出結果を図 6 中のプロットで示 す。 2 章の評価法による結果は, 数值解析結果に良く対応している。

図 7 に 6 層骨組での $M_{p B 1}$ 時及び $\Delta_{n} / H^{\prime}=0.02,0.03 \mathrm{rad}$ 時の(a)層間変 形角分布 $\delta_{f} / h,(\mathrm{~b})$ 主架構の層せん断力分布 $V_{f i} / W_{f}$, (c) 主架構の柱に作 用する柱頭曲げモーメント $M_{C t i} / M_{p B i}$, (d)連層柱作用曲げモーメント $M_{l i} / M_{p C 1}$ の高さ方向の分布について, 数值解析と 2 章の評価法によ る算出結果を比較する。縦軸は層数である。図 7(b)主架構の層せん 断力分布 $V_{f i} / W_{f}$ より, 弾性時において, $\eta=3.3$ では $\eta=0.03$ の場合に 比べて, より均一になることが確認できる。図 7 中に付記した\%数 值は, $\Delta_{n} / H^{\prime}=0.02 \mathrm{rad}$ 時における 2 章の評価法に対する数值解析結果 の誤差が最大となる層の誤差率を示している。2 章の評価法は, 連

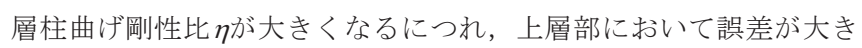
くなる傾向がみられるが, 数值解析結果とおおむ称良く対応してお り, 弾性範囲から保有水平耐力時まで骨組全体の力学性状を良く捉 えている。

なお，提案した修正 D 值法に基づく力学特性評価法（図 2) は, 連層柱曲げ岡性が十分に大きい場合において主架構の層せん断力分 布が概ね均一分布とみなせる骨組に対して適用可能である。梁断面 や柱断面の切り替えによる柱梁曲げ剛性比の直下の層に対する比 $\alpha_{j}$ が表 1 より小さい, 寸なわち上層で層剛性が顕著に小さくなるよう
な骨組については, 特に曲げモーメント分布で誤差が大きくなる傾 向があることを確認している。

\section{4. 連層柱を付与した層中間ピン柱脚骨組の静的な釣合方程式によ る評価法を用いた動的応答の予測}

\section{1 動的応答解析概要}

3.1 節に示す解析モデルを対象に, 連層柱を付与した層中間ピン 柱脚骨組の動的解析結果を 2 章で提案した静的な釣合方程式により 評価する。解析には 3 章と同様に OpenSees3.0.3 を用いる。動的応答 解析には平均加速度法を使用する。減衰はレイリー減衰を用いて 1 次と 2 次固有周期時の減衰をそれぞれ $h_{1}=h_{2}=0.02$ と定めた。地震波 は, El Centro1940, Hachinohe1968, Taft1952, Tohoku1978, JMA Kobe1995の NS 波とし, PGVを 0.25, 0.50, 0.75 m/s に調整した。計 算時間刻みは $0.02 \mathrm{~s}$ とした。なお, 本論文の検討では, P- $\Delta$ 効果は考 慮していない。図 8 に各地震波の加速度応答スペクトル $(\mathrm{PGV}=0.50$

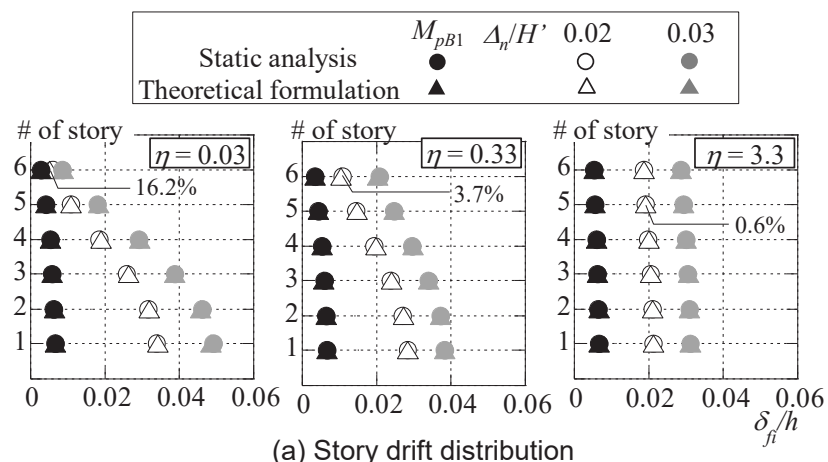

(a) Story drift distribution
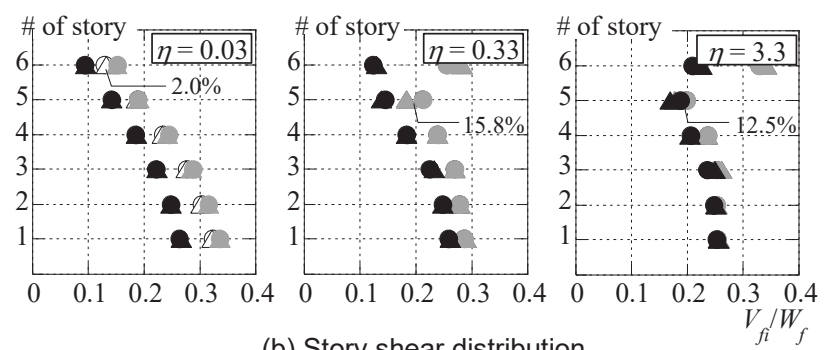

(b) Story shear distribution
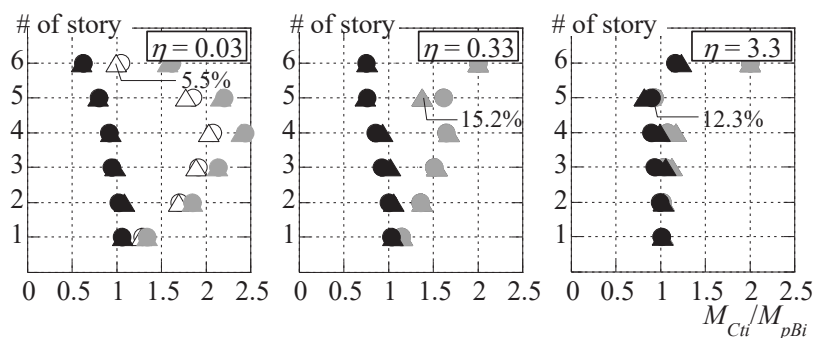

(c) Flexural moment distribution of column top
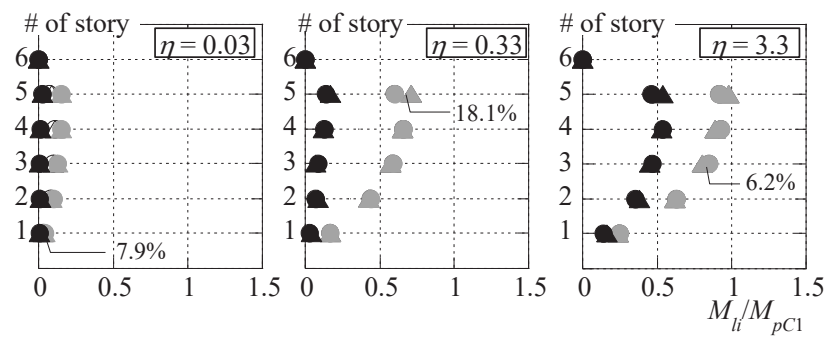

(d) Flexural moment distribution of M.L. column Fig.7 Structural mechanical characteristics (6-story frame) 


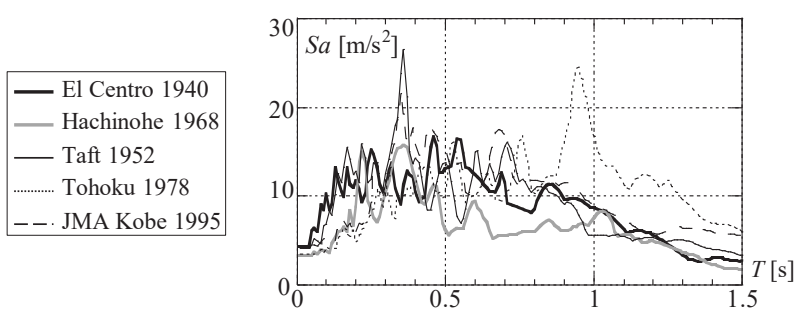

Fig.8 Pseudo acceleration response spectra $(h=0.05)$

Table 3 Natural period

\begin{tabular}{|c|l|l|l|l|l|l|l|l|c|}
\hline frame & \multicolumn{3}{|c|}{ 3-story } & \multicolumn{3}{c|}{ 6-story } & \multicolumn{3}{c|}{ 9-story } \\
\hline$\eta$ & 0.03 & 0.33 & 3.3 & 0.03 & 0.33 & 3.3 & 0.03 & 0.33 & 3.3 \\
\hline$T_{n 1}(\mathrm{~s})$ & 0.681 & 0.675 & 0.664 & 0.970 & 0.960 & 0.935 & 1.438 & 1.426 & 1.393 \\
\hline$T_{n 2}(\mathrm{~s}$ & 0.187 & 0.164 & 0.09 & 0.307 & 0.278 & 0.171 & 0.478 & 0.442 & 0.296 \\
\hline
\end{tabular}

\begin{tabular}{|l|l|l|l|l|l|l|l|l|l|}
\hline$T_{n 2}(\mathrm{~s})$ & 0.187 & 0.164 & 0.090 & 0.307 & 0.278 & 0.171 & 0.478 & 0.442 & 0.296 \\
\hline$T_{2}$ & 0.091 & 0.070 & 0.031 & 0.159 & 0.127 & 0.059 & 0.267 & 0.220 & 0.08 \\
\hline
\end{tabular}

\begin{tabular}{|l|l|l|l|l|l|l|l|l|l|}
\hline$T_{n 3}(\mathrm{~s})$ & 0.091 & 0.070 & 0.031 & 0.159 & 0.127 & 0.059 & 0.267 & 0.220 & 0.108 \\
\hline
\end{tabular}
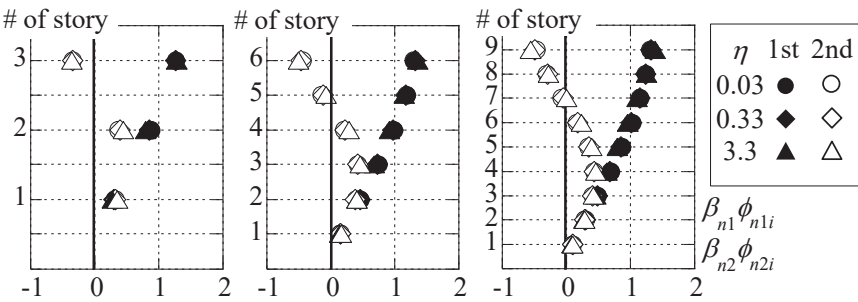

(a) 3-story frame

(b) 6-story frame Fig.9 Mode shape

$\mathrm{m} / \mathrm{s})$, 表 3 に 3,6 及び 9 層骨組 $(\eta=0.03,0.33,3.3)$ の 1 次から 3 次の固 有周期を示す。図 9 に 3,6 及び 9 層骨組 $(\eta=0.03,0.33,3.3)$ の 1 次と 2 次の刺激関数 $\beta_{n 1}\left\{\phi_{n 1}\right\}, \beta_{n 2}\left\{\phi_{n 2}\right\}$ を示す。表 3 より, 連層柱曲げ剛性比 $\eta$ によって 1 次固有周期はほぼ変わらないが, 2 次固有周期は $\eta=0.03$ に対して $\eta=3.3$ では半分程度となった。一方, 刺激関数は, 連層柱 曲げ剛性比 $\eta$ によらず，ほぼ等しい。

\subsection{Ai 分布による静的釣合方程式と動的応答解析の結果比較}

動的応答解析によって得た連層柱を付与した層中間ピン柱脚骨組 の力学特性を, 2 章の評価法により評価する。ここで, 2 章の評価法 では $\mathrm{Ai}$ 分布に基づいた外力分布を用いている。

動的応答解析では, 骨組の変形指標として(10)式 ${ }^{1)}$ とり算出でき る代表変位 $\Delta$ を用いる。さらに, 代表変位 $\Delta を, M_{p B 1}$ 時の代表変位 $\Delta_{p B 1}$ で無次元化した值（(11)式）を塑性変形倍率 $\mu$ 'と定義する。ここで, $m_{i}$ は $i$ 層質量とする。
$\Delta=\frac{\sum m_{i} \cdot \Delta_{i}^{2}}{\sum m_{i} \cdot \Delta_{i}}$
(10) $\quad \mu^{\prime}=\frac{\Delta}{\Delta_{p B 1}}$

図 10 に，6 層骨組を対象に(a)塑性変形倍率最大時 $\left(\mu_{\text {max }}^{\prime}\right)$ の層間 変形集中率 $\gamma,(b)$ 主架構の柱に作用する最大曲げモーメント $M_{C t i m a x} / M_{p B i}$, (c)連層柱の最大曲げモーメント $M_{l m a x} / M_{p C 1}$ と塑性変形 倍率 $\mu$ 'の関係を示す。 2 章の評価法は線で, 動的解析結果はプロッ 卜で示す。横軸の $\mu^{\prime}$ は動的解析結果の場合は最大值 $\mu^{\prime}{ }_{\text {max }}$ とする。(a), (c)は連層柱曲げ剛性比 $\eta=0.03,0.33,3.3$ について示し, (b)は連層柱 曲げ剛性比 $\eta=0.33,3.3$ について $1,3,5$ 層の $M_{C \text { timax }} / M_{p B i}$ を示す。なお, 図 10 に示寸 2 章の評価法と静的増分解析の結果は，概晞い対応 を示すことを確認している。(a)層間変形集中率 $\gamma$ と (b)主架構の柱に 作用する最大曲げモーメント $M_{\text {Ctimax }} / M_{p B i}$ は，連層柱曲げ剛性比 $\eta$ $=0.03,0.33$ では動的解析結果が 2 章の評価法に対して最大で 1.1 倍 となるが， $\eta=3.3$ ではほぼ等しくなる。一方，(c)連層柱の最大曲げ モーメント $M_{\text {lmax }} / M_{p C 1}$ は, 連層柱曲げ剛性比 $\eta=0.33,3.3$ において動 的解析結果が $\mathrm{Ai}$ 分布を用いた 2 章の評価法による予測值を大きく 上回り，最大で 2.0 倍となった。

\section{3 連層柱を付与した層中間ピン柱脚骨組の動的応答特性に対す る高次モードの影響}

図 1(a)でも示した通り，連層柱の下端ピン支持回りの剛体回転で は，連層柱に曲げモーメントは生じない。図 9 に示す刺激関数の形 状からも, 1 次モード応答より, 2 次モード以上の応答の方が，連層 柱に大きな曲げモーメントが作用すると考えられる。図 11 に 6 層 骨組 $(\eta=3.3)$ における El Centro $0.75 \mathrm{~m} / \mathrm{s}$ 及び Hachinohe $0.75 \mathrm{~m} / \mathrm{s}$ での, (a)代表変位 $\Delta$ と $1,3,5$ 層の骨組水平変位 $\Delta_{i}$, ， (b) 最大となる 4 層位置 の連層柱曲げモーメント $M_{l \max } / M_{p C 1}$, (c) $1,3,5$ 層の骨組全体一の作用 せん断力 $V_{s i}$ の $3 \mathrm{~s}$ 間の時刻歴を示す。図中にはそれぞれ塑性変形倍 率最大時 $(\triangle)$, 連層柱最大曲げモーメント作用時 $(\boldsymbol{\Delta})$ も示寸。6 層骨組 $(\eta=3.3)$ の 1 次と 2 次の固有周期は $0.935 \mathrm{~s}$ と $0.171 \mathrm{~s}$ （表 3) である。(a)骨組水平変位は 1 次モードが支配的であるのに対し，(b) 連層柱曲げモーメント $M_{l \max } / M_{p C 1}$ は高次モードの影響を無視できな いことが分かる。(b)連層柱曲げモーメント $M_{l \max } / M_{p C 1}$ は，(a)の代表 変位の振幅の最大（最小）時ではなく，その直前および直後に振幅 が最大となる (図中の山)。また，(c)骨組全体への作用せん断力は， 塑性変形倍率最大時に $1,3,5$ 層が等しくなる傾向にあり，連層柱最
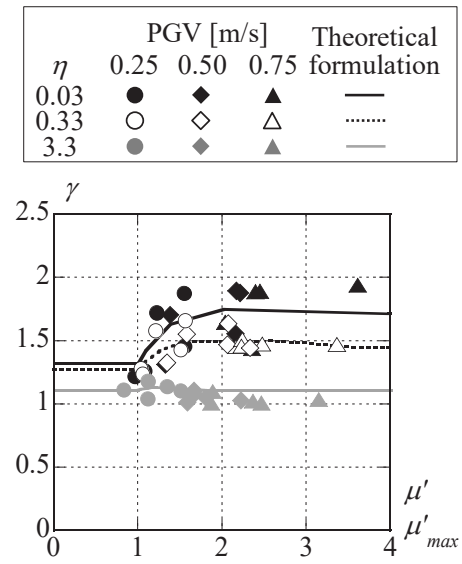

(a) story drift concentration rate

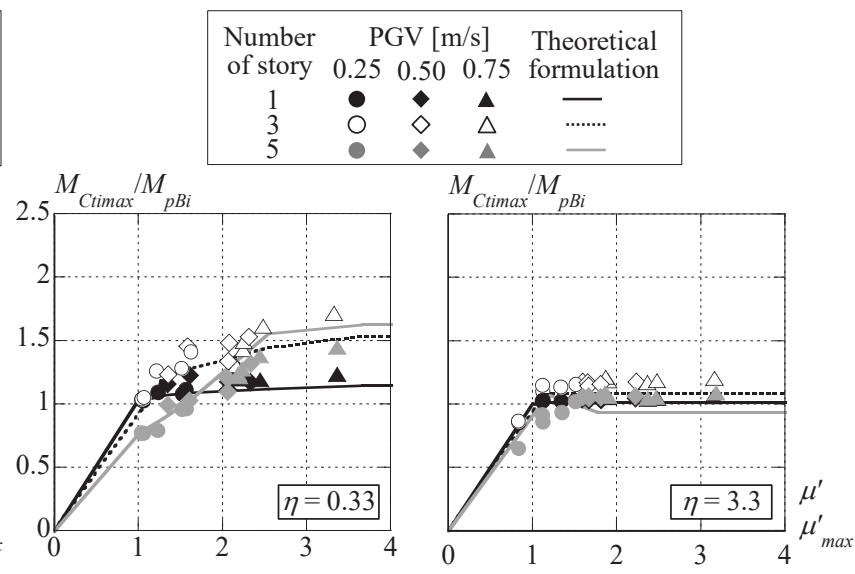

(b) maximum flexural moment of column top

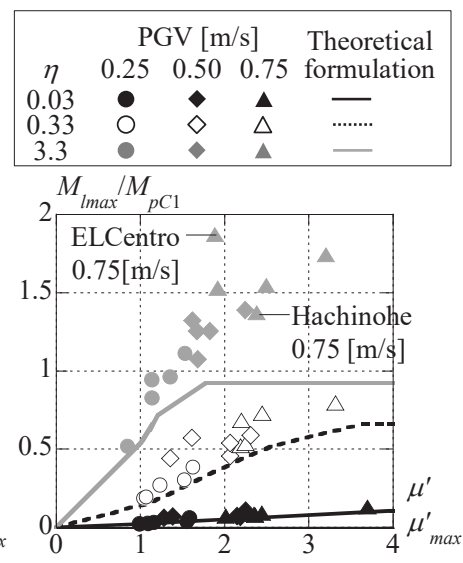

(c) maximum flexural moment of M.L. column

Fig.10 Relation between dynamic simulation and Theoretical formulation with respect to equivalent plasticity rate (6-story frame) 

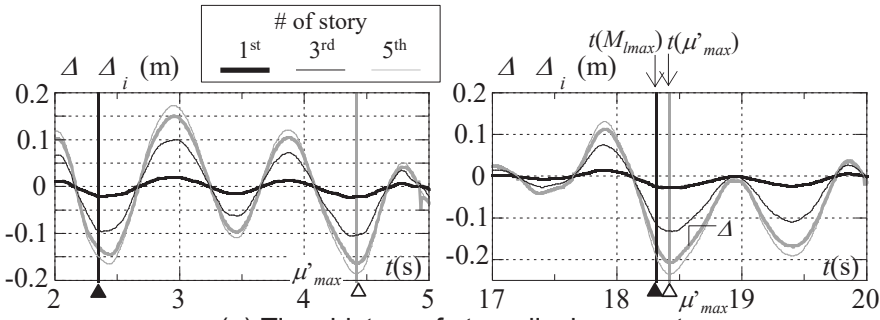

(a) Time history of story displacement
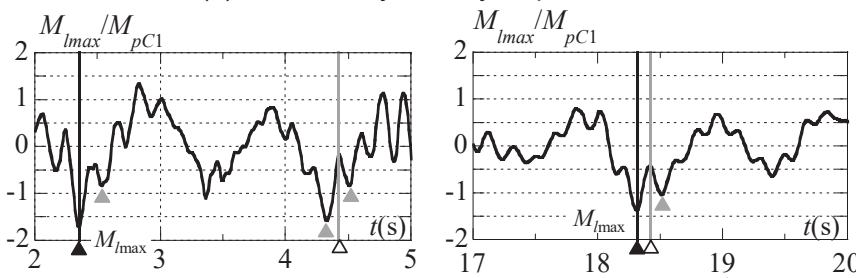

(b) Time history of flexural moment of M.L column ( $4^{\text {th }}$ floor)

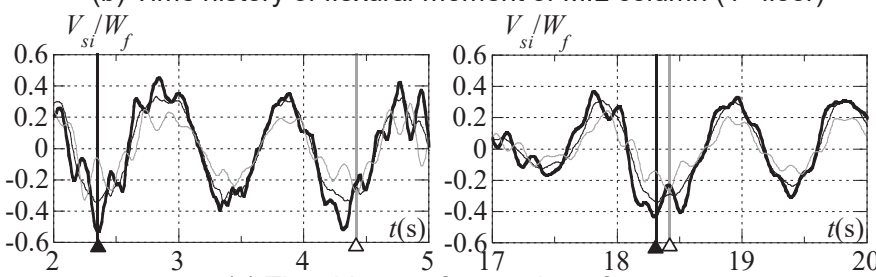

(c) Time history of story shear force

Fig. 11 Response time histories of 6-story frame with M.L. column of $\eta=3.3$; Left side: El Centro 1940 (PGV=0.75 m/s), Right side: Hachinohe 1968 (PGV=0.75 m/s)

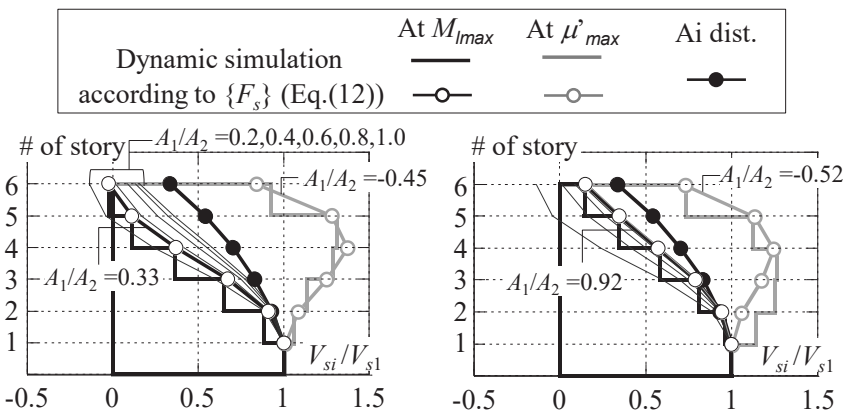

Fig. 12 Story shear distribution of 6 -story frame with M.L. column of $\eta=3.3$; Left side: El Centro 1940 (PGV=0.75 m/s), Right side: Hachinohe 1968 ( $P G V=0.75 \mathrm{~m} / \mathrm{s})$

大曲げモーメント作用時には 1 層が大きく, 3,5 層と上層ほど小さ くなる傾向を示す。

図 12 に 6 層骨組 $(\eta=3.3)$ における El Centro $0.75 \mathrm{~m} / \mathrm{s}$ 及び Hachinohe $0.75 \mathrm{~m} / \mathrm{s}$ での, 塑性変形倍率最大時及び，連層柱最大曲げモーメン 卜作用時の骨組全体への作用せん断力 $V_{s i}$ を 1 層作用せん断力 $V_{s 1}$ で 無次元化したせん断力比の高さ方向分布（せん断力比分布と呼称す る）を示す。縦軸は層数である。図には $\mathrm{Ai}$ 分布に対するせん断力比 分布（○）も示す。図 12 には, 動的解析結果を(12)式で近似した外 力分布 $\left\{F_{s}\right\}$ によるん断力比分布 $(O)$ も示寸。ここで，(12)式では 1 次と 2 次モードの刺激関数 (図 9) に任意の応答加速度 $\left(A_{1}\right.$ と $\left.A_{2}\right)$ を乗じることで，外力分布 $\left\{F_{s}\right\}$ を算出する。

$$
\left\{F_{s}\right\}=A_{1} \beta_{n 1}\left\{\phi_{n 1}\right\}+A_{2} \beta_{n 2}\left\{\phi_{n 2}\right\}
$$

図 12 より, 塑性変形倍率最大時, 連層柱最大曲げモーメント作用 時のせん断力比分布は, 共に $\mathrm{Ai}$ 分布（の）には対応していないこと が分かる。塑性変形倍率最大時は中層のせん断力が 1 層に対してよ り大きくなる。一方，連層柱最大曲げモーメント作用時は上層に対
して 1 層のせん断力が特に大きくなる。つまり, 塑性変形倍率最大 時では 2 次モードと 1 次モードは逆位相 $\left(A_{1} / A_{2}<0\right)$, 連層柱最大曲 げモーメント作用時では 2 次モードと 1 次モードは同位相 $\left(A_{1} / A_{2}>0\right)$ に作用している。動的解析結果は，2 次モード応答までを考慮した (12)式で近似したせん断力比分布（図 12 中の○）と良く対応し，連 層柱最大曲げモーメント作用時におけるせん断力比分布において,

(12)式で近似した場合の $A_{1} / A_{2}$ は, El Centro $0.75 \mathrm{~m} / \mathrm{s}$ で 0.33 , Hachinohe $0.75 \mathrm{~m} / \mathrm{s}$ で 0.92 となる。

\section{4 動的地震外力に対する高次モード応答を考慮した連層柱最大 曲げモーメント評価法}

本節では，任意の地震動に対する連層柱に作用する最大曲げモ一 メントを算出する方法を, 梁の降伏進展に伴う連層柱一の応力再配 分を考慮できる，2 章の評価法に基づいて提案する。図 13 に，任意 の地震動に対する連層柱に作用する最大曲げモーメントを算出する 方法を示す。図 13(a)に示す主要な計算フローは，(1) (6)で構成され る。(1)で主架構と連層柱，(2)で地震動を選定する。(3)で(2)の地震動 入力時の骨組の等価塑性変形倍率 $\mu_{e}$ 'を算出し, (4)で地震動入力時の 連層柱最大曲げモーメントが作用するときの外力分布 $\left\{F_{\text {slmax }}\right\}$ を算 出する。(5)で 2 章の評価法を用いて(4)で得た外力分布に比例する外 力を(3)で得た骨組の等価塑性変形倍率 $\mu_{e}$ 'に達するまで作用させる ことにより，(6)で連層柱最大曲げモーメントを算出する。ここで, (3)の等価塑性変形倍率 $\mu_{e}{ }^{\prime}$ は図 $13(\mathrm{~b})$ のフロー, (4)の外力分布は図 13(c)のフローに従って算出する。

図 13(b)より，任意の地震動に対する骨組の等価塑性変形倍率 $\mu_{e}$ ' は，等価線形化法により算出する。図 13(d)に, El Centro $0.75 \mathrm{~m} / \mathrm{s}$ の 場合を例に $S a-S d$ 曲線を示し, 6 層骨組 $(\eta=3.3)$ の性能曲線を黒太線, (13)式 ${ }^{1)}$ より算出される要求曲線を灰太破線で併せて示す。 $S a-S d$ 曲 線の縦軸は加速度応答スペクトルを重力加速度 $G$ で無次元化した 值，横軸は変位応答スペクトルを $M_{p B 1}$ 時の代表変位 $\Delta_{p B 1}$ で無次元化 した值である。ここで， $M_{p B 1}$ 時の代表変位 $\Delta_{p B 1}$ は，Ai 分布に基づく 外力分布を用いて 2 章の評価法により算出する。性能曲線の縦軸は 骨組第 1 層せん断力 $V_{\mathrm{s} 1}$ を 1 次有効質量 $M_{e f 1}$ で除し, 重力加速度 $G$ で無次元化した值である。性能曲線と要求曲線の交点から, 入力地 震動に対する骨組の等価塑性変形倍率 $\mu_{e}$ 'を求める。

前節では，任意の地震動に対して連層柱最大曲げモーメントが作 用するときの外力分布 $\left\{F_{\text {slmax }}\right\}$ は，1 次と 2 次モードの刺激関数に任 意の応答加速度 $\left(A_{1}\right.$ と $\left.A_{2}\right)$ を乗じた(12)式で表現できることが示さ れている。そこで，本論文では(12)式の応答加速度 $\left(A_{1}\right.$ と $\left.A_{2}\right)$ を， 1 次モード応答加速度 $S_{a 1}$ と 2 次モード応答加速度 $S_{a 2}$ と仮定し, 外 力分布 $\left\{F_{\text {slmax }}\right\}$ を(15)式で定義する。図 12 に示した El Centro $0.75 \mathrm{~m} / \mathrm{s}$, Hachinohe $0.75 \mathrm{~m} / \mathrm{s}$ の $S_{a 1} / S_{a 2}$ を算出すると $0.39 ， 0.89$ となり，(12)式 で近似した場合の $A_{1} / A_{2}$ と良く対応する。 $S_{a 1}$ と $S_{a 2}$ は図 $13(\mathrm{e})$ に示す ように加速度応答スペクトルより求める。ここで, 固有周期は弾性 時の固有周期 $\left(T_{n 1}, T_{n 2}\right)$ を用いる。1 次モードの減衰率 $h_{1}$ は, 骨組 の塑性変形による履歴減衰を考慮し, 図 13(b)で算出した等価塑性変 形倍率 $\mu_{e}$ 'を用いて(13)式より算出する。2 次モードの減衰率 $h_{2}$ は鋼 構造の弾性応答時の減衰率である 0.02 を使用する（(14)式）。

以上より，(14),(15)式で求めた $\left\{F_{\text {slmax }}\right\}$ を外力分布として用いて，骨 組の塑性変形倍率が $\mu_{e}$ 'に達寸る時（図 13(f)）の力学特性を 2 章の評 価法で算出することで，任意の地震動に対する連層柱最大曲げモー 


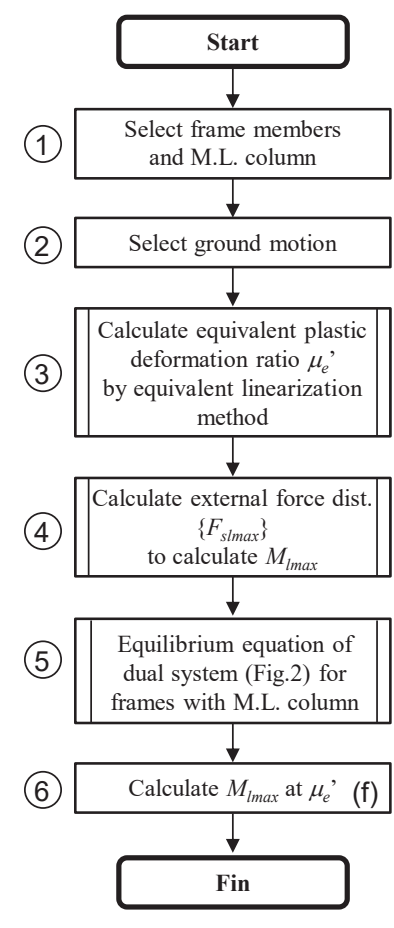

(a) Main flow

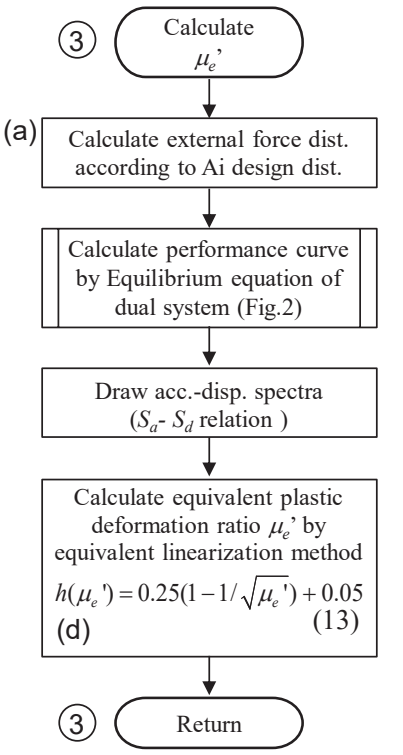
(b) Flow to calculate equivalent
plastic deformation ratio

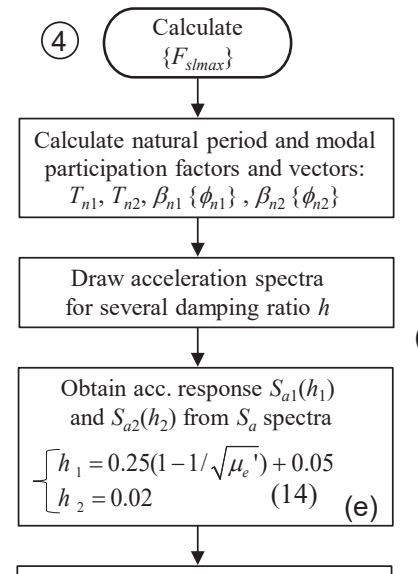

Calculate external force dist. considering second mode response

$\left\{F_{s l \text { max }}\right\}=S_{a 1}\left(T_{n 1}, h_{1}\right) \times \beta_{n 1}\left\{\phi_{n 1}\right\}$

$+S_{a 2}\left(T_{n 2}, h_{2}\right) \times \beta_{n 2}\left\{\phi_{n 2}\right\}(15)$

(4)

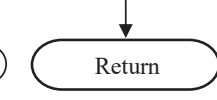

(c) Flow to calculate external force considering second mode response

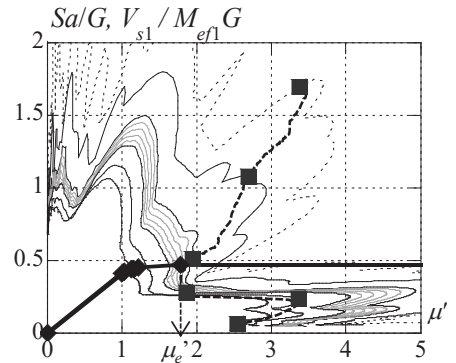

(d) Obtain equivalent plastic deformation ratio by equivalent linearization method

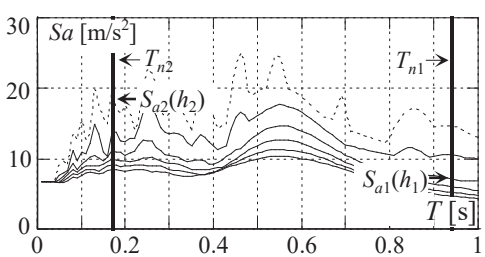

(e) Obtain acc. response at $T_{n 1}$ and

$T_{n 2}$ from acc. response spectra

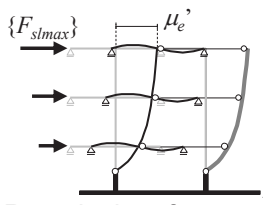

(f) Re-calculate frame responses by new external force distribution

Fig.13 Flow chart to calculate the maximum flexural moment of M.L. column $M_{l \max }$ for given earthquake ground motion

メント $M_{\operatorname{lmax}}$ を評価する。

\section{5 高次モードを考慮した静的地震外力を用いた連層柱最大曲げ モーメントの評価}

4.4 節で提案した評価法の適用性を検討するため, 図 8 の 5 波に 加えて, 2000 年以降に震度 6 強以上を記録した 9 つの地震から PGA が特に大きい記録地震波 NS 波を 3 波ずつ採用し, 計 32 波の地震波 を用いた動的応答解析を行った。図 14(a),(b),(c)に 3,6,9 層骨組の連 層柱最大曲げモーメントの動的解析結果と図 13 に示寸評価法との 関係を示す。それぞれに $\eta=0.03,0.33,3.3$ の結果を示す。横軸は評価 值, 縦軸は動的解析結果である。ここでは, 図 8 の 5 波に加えて, 2000 年以降に震度 6 強以上を記録した 9 つの地震から, PGA が特 に大きい記録地震動を 3 波ずつ, 計 27 波の NS 波を新たに採用し た。図 14 には, PGVを 0.25, 0.50, $0.75 \mathrm{~m} / \mathrm{s}$ とした時の結果を示す。 付録 2 に, 追加した地震波の情報を示寸。図 14 において特に連層柱
作用曲げモーメントが大きくなった地震波は鳥取県西部地震 2000 Niimi 波や新潟県中越沖地震 2007 Teradomari 波などで, いずれも $0.2 \mathrm{~s}$ 程度の短周期成分が支配的な地震波であった (付録 2 参照)。連層柱 曲げ剛性比が十分に大きい $\eta=3.3$ では, 3,6,9 層骨組いずれも全体の 約 $84 \%$ が危険側の誤差 $10 \%$ 以内にとどまり，良い対応を示す。 $\eta=$ 3.3 と比較して半分程度の損傷集中抑制効果が得られる $\eta=0.33$ で は，3,6 層骨組では概ね良い対応を示す。一方，9層骨組ではばらつ きが大きくなる傾向がみられ，全体の約 35\%が危険側の誤差 20\%を 超えた。これは, $\eta=0.33$ の連層柱を付与した 9 層骨組では, 3 次 固有周期と地震動の周期帯域が重なり，3 次モードが励起されるた めと考えられる（表 3)。なお，(15)式において 3 次モードを考慮す ることで,危険側評価を $10 \%$ 以下に抑えられることを確認している。 本論文の解析的検討では P- $\Delta$ 効果を考慮していない。P- $\Delta$ 効果を考 慮した場合，図 14 において連層柱作用曲げモーメントが大きくな

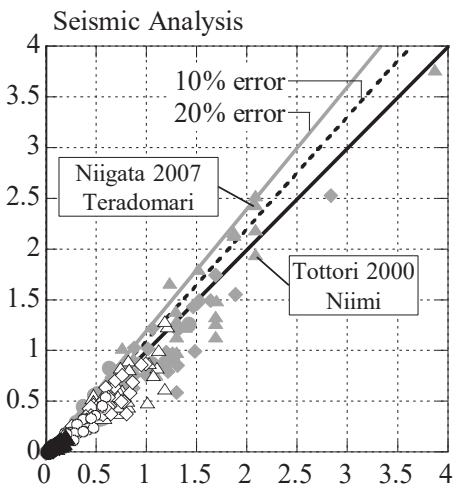

(a) 3-story frame

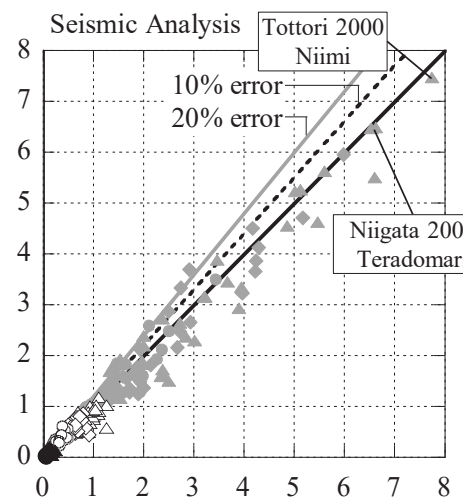

(b) 6-story frame

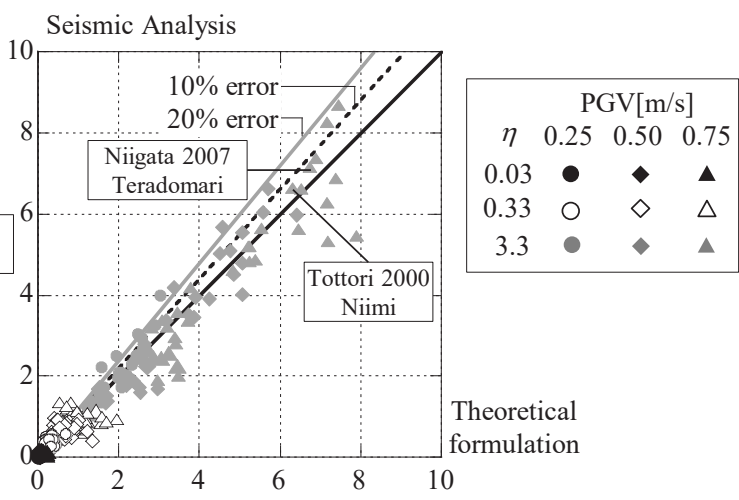

(c) 9-story frame

Fig.14 Comparison between seismic simulation result and estimation for the maximum flexural moment of M.L. column normalized by plastic moment of the first story column $M_{I m a x} / M_{C p 1}$ 
るような短周期成分が支配的な地震波では, P- $\Delta$ 効果による増加率は いずれも $4 \%$ 以下に留まることを確認している。

\section{5. 結}

1) 2 章において, 連層柱を付与した層中間ピン柱脚骨組における主 架構及び連層柱の水平変位, せん断力分布・曲げモーメントを導出 するため, 修正 D 值法を利用した水平外力に対する静的な釣合方程 式による力学特性評価法 (図 2) を提案し, 3 章で静的増分解析によ りその妥当性を示した。

2) 3 章において, 連層柱曲げ剛性比の主架構の力学特性への影響を, 静的増分解析及び 2 章の評価法により検討した。3,6,9 層いずれの骨 組においても, 層間変形集中率 $\gamma$ 及び主架構の柱に作用する最大曲げ モーメント $M_{C t i m a x} / M_{p B i}$ は, 連層柱曲げ剛性比が概敉 $\eta=3.3$ で主架構 の層間変形角や曲げモーメントが全層に渡って均一となる効果が得 られる。 $\eta=0.03$ 程度から連層柱の損傷集中抑制効果が発揮され, 連 層柱曲げ剛性比 $\eta=0.33$ で剛な場合の半分程度の損傷集中抑制効果 が得られる。

3) 4 章において, 層間変形集中率 $\gamma$ 及び主架構の柱に作用する最大曲 げモーメント $M_{C t \text { timax }} / M_{p B i}$ の動的解析結果は, $\eta=0.03,0.33,3.3$ にお いて $\mathrm{Ai}$ 分布を用いた 2 章の評価法による予測值と良く対応し, 最 大で 1.1 倍程度となることを示した。一方で, 連層柱最大曲げモー メント $M_{\operatorname{lmax}}$ の動的解析結果は, $\mathrm{Ai}$ 分布を用いた 2 章の評価法によ る予測值を大きく上回り, 最大で 2.0 倍となった。これは高次モー ドの影響であることを明らかにした。

4) 3)の知見を基に 4.4 節ではモード分解法を用いて, 骨組の 2 次モ ード応答を考慮した連層柱最大曲げモーメント $M_{\operatorname{lmax}}$ の算出法を提 案した（図 13）。提案する評価法を用いると, 連層柱曲げ剛性比 $\eta=$ 0.33 の 9 層骨組では誤差が大きくなる傾向が見られるが, 連層柱曲 げ剛性比が十分に剛な場合と 3,6 層骨組 $\eta=0.33$ では, 連層柱最大曲 げモーメント $M_{l \max }$ の動的解析結果を良い精度で予測できる。

5） 6 層骨組が保有水平耐力時に全層梁降伏メカニズムを形成する ためには, 連層柱曲げ剛性比 $\eta=0.03$ では $2.1, \eta=0.33$ では $1.4, \eta=3.3$ では 1.1 程度の主架構柱梁耐力比 $M_{p C i} / M_{p B i}$ が必要となる。さらに, 連層柱を弾性に保つためには， $0.25 ， 0.50,0.75 \mathrm{~m} / \mathrm{s}$ の全地震波に対 して, $\eta=0.33$ では主架構柱の $0.6,0.9,1.2$ 倍, $\eta=3.3$ では主架構柱 の $3.5,6.0,7.5$ 倍程度の曲げ耐力が必要となる。

\section{謝辞}

本研究は, JST 産学共創プラットフォーム共同研究推進プログラム及 び科学研究費補助金基盤研究(B)(課題番号 19H02280)によるものである。 また, 本研究に取り組むにあたり, 東京工業大学名誉教授の和田章先生 と構造計画プラス・ワン会長の金田勝徳先生にご指導いただいた。ここ に深く感謝の意を示す。

\section{参考文献}

1) National Institute for Land and Infrastructure Management Ministry of Land, Infrastructure, Transport and Tourism, Japan. Building Research Institute, National Research and Development Agency.: Structural related technical standard commentary on buildings - 2015 edition, 2015(in Japanese)

2) Shimada, Y., Suita, K., Yamada, S., Matsuoka, Y., Tada, M., Ohsaki, M. and Kasai, K.: Experimental Procedure and Elastic Response Characteristics of
Shaking Table Test - Complete Collapse Test of Full-Scale 4-Story Steel Building Part 3, Journal of Structural and Construction Engineering (Transactions of AIJ), Vol. 75, No. 653, pp.1351-1360, 2010.7 (in Japanese)

3) Kaneda, K., Kimura, Y., Hamasaki, S. and Wada, A.: Proposal of New Column Support System for Multi-Story Moment Resisting Structures to Perform Beam Yielding Mechanism, Journal of Structural and Construction Engineering (Transactions of AIJ), Vol. 75, No. 654, pp.1537-1546, 2010.8 (in Japanese)

4) Kaneda, K., Kimura, Y., Miyahara, N. and Wada, A.: Ultimate Seismic Capacity of Multi-Story Steel Moment Resisting Frames Having New Column Support System, Journal of Structural and Construction Engineering (Transactions of AIJ), Vol. 76, No. 661, pp.649-658, 2011.3 (in Japanese)

5) Kimura, Y., Kaneda, K. and Wada, A.: Estimation of Ultimate Seismic Capacity and Column Demand of Multi-Story Steel Moment Resisting Frames with New Column Support System to Fishbone-Shaped Frame, Journal of Structural and Construction Engineering (Transactions of AIJ), Vol. 77, No. 675, pp.765-773, 2012.5 (in Japanese)

6) Kimura, Y., Kaneda, K. and Wada, A.: Estimation of Shear and Axial Force for Steel Column Joints and Seismic Strength of Multi-Story Steel Moment Resisting Frames with New Column Support System, Journal of Structural and Construction Engineering (Transactions of AIJ), Vol. 78, No. 688, pp.11491158, 2013.6 (in Japanese)

7) Kaneda, K., Kimura, Y., Mutsukura, K., Kadoya, H., Watanabe, T. and Takahashi, K.: Cyclic Loading Test for Partial Frames with New Column Support System for Multi-Story Steel Moment Resisting Structures to Perform Beam Yielding Mechanism, Journal of Structural and Construction Engineering (Transactions of AIJ), Vol. 76, No. 665, pp.1357-1366, 2011.7 (in Japanese)

8) Wada, A., Uchiyama, Y., Kishiki, S., Ito, H., Sakata, H. and Motoyui, S.: Seismic Retrofit of Existing RC Building with Rocking Wall Part1,2, Summaries of Technical Papers of Annual Meeting, Architectural Institute of Japan, Structures-IV pp.623-626, 2010.7 (in Japanese)

和田章, 内山裕太, 吉敷祥一, 伊藤浩資, 坂田弘安, 元結正次郎：ロッ キング壁による既存 RC 建物の耐震改修その 1,2 , 日本建築学会大会 学術講演梗概集, 構造 IV, pp.623-626, 2010.7.

9) MacRae, G. A., Kimura, Y., Roeder, C.: Effect of Column Stiffness on Braced Frame Seismic Behaviour, Journal of Structural Engineering, ASCE, Vol.130, No.3, pp.381-391, 2004.3

10) Kimura, Y. and MacRae, G. A.: Effect of Column Flexural Stiffness and Strength on Story Drift Concentration Mechanism of 2 Story Braced Frames with Fixed Column Base, Journal of Structural and Construction Engineering (Transactions of AIJ), No. 593, pp.153-160, 2005.7 (in Japanese)

11) Kimura, Y., Matsuo, Y. and Nakazawa, Y.: Story Drift Concentration and Hysteresis Energy for Two Story Braced Frame with Buckling Braces Subjected to Strong Motion, Journal of Structural and Construction Engineering (Transactions of AIJ), Vol. 77, No. 672, pp.293-301, 2012.2 (in Japanese)

12) Akiyama, H. and Takahashi, M.: Ds-Values for Damage-Dispersing Type MultiStory Frames, Transactions of the Architectural Institute of Japan, No. 341, pp.54-61, 1984.7 (in Japanese)

13) Alavi, B. and Krawinkler, H.: Strengthening of moment-resisting frame structures against near-fault ground motion effects, Earthquake Engineering and Structural Dynamics, Vol. 33, pp.707-722, 2003.

14) Qu, Z., Wada, A., Motoyui, S., Sakata, H. and Kishiki, S.: Pin-supported walls for enhancing the seismic performance of building structures, Earthquake Engineering and Structural Dynamics, Vol.41, pp.2075-2091, 2012.

15) Kimura, Y., Otsuka, Y. and Furukawa, S.: Required Flexural Strength and Damage Reduction Effect of Leaning Column on Prevention of Column Yielding of Steel Moment Resisting Frame, Proceedings of Constructional Steel, Vol. 21, pp.492-497, 2013.11 (in Japanese) 木村祥裕, 大塚友里, 古川幸 : 全層梁降伏型骨組に付与した弾性柱の必 要曲げ耐力と損傷低減効果, 鋼構造年次論文集, 第 21 号, pp.492-497, 2013.11

16) Kimura, Y., Ando, M. and Furukawa, S.: Modified D-Value Method to Predict Seismic Strength of Multi-Story Steel Moment Resisting Frames with Mid- 
Story Pin Column Base System, Journal of Structural and Construction Engineering (Transactions of AIJ), Vol. 85, No. 767, pp.117-127, 2020.1 (in Japanese)

17) Muto, K.: Seismic Calculation Method, Maruzen, 1963 (in Japanese)

18) Building Research Institute.: Cold-formed square steel pipe design and construction manual - 2008 edition, 2008.12 (in Japanese)

19) Strong-motion Seismograph network (K-NET, Kik-net), download on 2020.1.24, National Research Institute for Earth Science and Disaster Resilience.

付録 1：3 層骨組を例にした静的な釣合方程式による力学特性の算出

連層柱の層せん断力 $V_{l i}$ と連層柱のたわみ $\delta_{l i}$ の釣合方程式(3)式は, 図 2 中 (3)式上に示寸力学モデルについて仮想仕事法で (付 1)式となる。ここで, $F_{l i}$ は繋ぎ梁から連層柱に作用する水平荷重である。

$$
\left\{\begin{array}{c}
\delta_{l 1} \\
\delta_{l 2}
\end{array}\right\}=\frac{h^{3}}{30 E_{M L} I_{M L}}\left[\begin{array}{ll}
4 & 5 \\
5 & 9
\end{array}\right]\left\{\begin{array}{l}
F_{l 1} \\
F_{l 2}
\end{array}\right\}
$$

水平荷重 $F_{l i}$ と連層柱の作用せん断力の関係 $\left(F_{l 1}=V_{l 1}-V_{l 2}=-3 V_{l 2}-2 V_{l 3}, F_{l 2}=V_{l 2}-V_{l 3}\right)$ により，(付 2)式を得る。下端ピン支持周りの回転力の釣り合い式(5)式より， $V_{c 1}$ は(付 3)式となる。

$$
\left\{\begin{array}{l}
V_{l 2} \\
V_{l 3}
\end{array}\right\}=\frac{6 E_{M L} I_{M L}}{11 h^{3}}\left[\begin{array}{cc}
-19 & 13 \\
6 & -7
\end{array}\right]\left\{\begin{array}{c}
\delta_{l 1} \\
\delta_{l 2}
\end{array}\right\} \text { (付 2) } \quad V_{l 1}=-2\left(V_{l 2}+V_{l 3}\right) \text { (付 3) }
$$

一方, 主架構の釣り合い方程式（(3)式）は,

$$
\left\{\begin{array}{l}
V_{f 3} \\
V_{f 2} \\
V_{f 1}
\end{array}\right\}=\left[\begin{array}{lll}
K_{f 3} & & \\
& K_{f 2} & \\
& & K_{f 1}
\end{array}\right]\left\{\begin{array}{l}
\delta_{f 3} \\
\delta_{f 2} \\
\delta_{f 1}
\end{array}\right\}
$$

骨組全体に作用する水平外力との力の釣り合い方程式（(7)式）は，(付 5)式 となる。ここで, $V_{s 2}, V_{s 3}$ はせん断力比 $X_{2}, X_{3}$ を用いて, $V_{s 1}$ で表す。一方, 適合 条件式 ((6)式) は(付 6)式となる。

$$
\left\{\begin{array}{l}
V_{s 3} \\
V_{s 2} \\
V_{s 1}
\end{array}\right\}=\left\{\begin{array}{c}
X_{3} V_{s 1} \\
X_{2} V_{s 1} \\
V_{s 1}
\end{array}\right\}=\left\{\begin{array}{l}
V_{f 3} \\
V_{f 2} \\
V_{f 1}
\end{array}\right\}+\left\{\begin{array}{l}
V_{l 3} \\
V_{l 2} \\
V_{l 1}
\end{array}\right\} \text { (付 5) }\left\{\begin{array}{l}
\delta_{l 3} \\
\delta_{l 2} \\
\delta_{l 1}
\end{array}\right\}=\frac{h}{H^{\prime}}\left[\begin{array}{ccc}
0 & 0 & 0 \\
2 & 2 & -3 \\
4 & -1 & 1
\end{array}\right]\left[\begin{array}{l}
\delta_{f 3} \\
\delta_{f 2} \\
\delta_{f 1}
\end{array}\right\} \text { (付 6) }
$$

(付 6)式と(付 4)式を(付 5)式に代入することで,

$$
\left\{\begin{array}{l}
\delta_{l 1} \\
\delta_{l 2}
\end{array}\right\}=\frac{1}{5}\left[\begin{array}{ccc}
\frac{4}{K_{f 1}}-C_{1} & \frac{1}{K_{f 2}}+2 C_{1} & \frac{1}{K_{f 3}}+2 C_{1} \\
\frac{2}{K_{f 1}}-C_{2} & -\frac{2}{K_{f 1}}+2 C_{2} & \frac{3}{K_{f 1}}+2 C_{2}
\end{array}\right]\left\{\begin{array}{l}
V_{f 1} \\
V_{l 2} \\
V_{l 3}
\end{array}\right\} \quad\left\{\begin{array}{l}
C_{1} \\
C_{2}
\end{array}\right\}=\left\{\begin{array}{c}
\frac{X_{2}}{K_{f 2}}+\frac{X_{3}}{K_{f 3}} \\
-2 \frac{X_{2}}{K_{f 2}}+3 \frac{X_{3}}{K_{f 3}}
\end{array}\right\}
$$

(付 2)式，(付 7)式より，

$$
\begin{gathered}
\left\{\begin{array}{l}
V_{l 3} \\
V_{l 2} \\
V_{l 1}
\end{array}\right\}=\left\{\begin{array}{c}
x_{3} \\
x_{2} \\
-2\left(x_{2}+x_{3}\right)
\end{array}\right\} V_{f 1} \\
x_{2}=-\left\{\frac{4}{K_{f 1}}-C_{1}+\left(\frac{1}{K_{f 3}}+2 C_{1}+\frac{13 h^{3}}{6 E_{M L} I_{M L}}\right) x_{3}\right\} /\left\{\frac{1}{K_{f 2}}+2 C_{1}+\frac{7 h^{3}}{6 E_{M L} I_{M L}}\right\} \\
x_{3}=-\left\{\left(\frac{4}{K_{f 1}}-C_{1}\right)\left(-\frac{2}{K_{f 2}}+2 C_{2}+\frac{h^{3}}{E_{M L} I_{M L}}\right)-\left(\frac{2}{K_{f 1}}-C_{2}\right)\left(\frac{1}{K_{f 2}}+2 C_{1}+\frac{7 h^{3}}{6 E_{M L} I_{M L}}\right)\right\} / \\
\left\{\left(\frac{1}{K_{f 3}}+2 C_{1}+\frac{13 h^{3}}{6 E_{M L} I_{M L}}\right)\left(-\frac{2}{K_{f 2}}+2 C_{2}+\frac{h^{3}}{E_{M L L} I_{M L}}\right)-\left(\frac{3}{K_{f 1}}+2 C_{2}+\frac{19 h^{3}}{6 E_{M L} I_{M L}}\right)\left(\frac{1}{K_{f 2}}+2 C_{1}+\frac{7 h^{3}}{6 E_{M L} I_{M L}}\right)\right\}
\end{gathered}
$$

(付 5)式, (付 8)式より,

$$
\left[\begin{array}{ccc}
1 & 0 & x_{3} \\
0 & 1 & x_{2} \\
0 & 0 & 1-2\left(x_{2}+x_{3}\right)
\end{array}\right]\left\{\begin{array}{c}
V_{f 3} \\
V_{f 2} \\
V_{f 1}
\end{array}\right\}=\left\{\begin{array}{c}
X_{3} \\
X_{2} \\
1
\end{array}\right\} V_{s 1}
$$

以上より, 3 層骨組の各層水平変位とせん断力分布が算出される。主架構の 柱曲げモーメント分布は修正 D 值法 ${ }^{16)}$ で求められる各層反曲点高さ比を用い

\begin{tabular}{|c|c|c|c|}
\hline Earthquake & \multicolumn{3}{|c|}{ Location /(Record) } \\
\hline \multirow{2}{*}{$\begin{array}{l}\text { Tottori-ken Seibu } \\
\text { Earthquake } 2000 \\
\end{array}$} & Niimi & Kofu & Nichinan \\
\hline & (OKY004) & (TTR007) & (TTR009) \\
\hline \multirow{2}{*}{$\begin{array}{l}\text { Niigata-ken Chuetsu } \\
\text { Earthquake } 2004\end{array}$} & Tokamachi & Ojiya & Koide \\
\hline & (NIG021) & (NIG019) & (NIG020) \\
\hline \multirow{2}{*}{$\begin{array}{l}\text { Fukuoka-ken Oki } \\
\text { Earthquake 2005 }\end{array}$} & Hirado & Karatsu & Chinzei \\
\hline & (NGS001) & (SAG002) & (SAG001) \\
\hline \multirow{2}{*}{$\begin{array}{c}\text { Noto Hanto Earthquake } \\
2007\end{array}$} & Togi & Anamizu & Noto \\
\hline & (ISK006) & (ISK005) & (ISK004) \\
\hline \multirow{2}{*}{$\begin{array}{c}\text { Niigata-ken Chuetsu Oki } \\
\text { Earthquake } 2007\end{array}$} & Kashiwazaki & Ojiya & Teradomari \\
\hline & (NIG018) & (NIG019) & (NIG016) \\
\hline \multirow{2}{*}{$\begin{array}{c}\text { Iwate-Miyagi Nairiku } \\
\text { Earthquake } 2008\end{array}$} & Tsukidate & Naruko & Tsubakidai \\
\hline & (MYG004) & (MYG005) & (AKIT023) \\
\hline \multirow{2}{*}{$\begin{array}{c}\text { Ibaraki-ken Oki } \\
\text { Earthquake } 2011\end{array}$} & Hitachi & Hokota & Imaichi \\
\hline & (IBR003) & (IBR013) & (TCG009) \\
\hline \multirow{2}{*}{$\begin{array}{c}\text { Hokkai-do Ibuki Tobu } \\
\text { Earthquake } 2018\end{array}$} & Oiwake & Hobetsu & Horokeshi \\
\hline & (HKD127) & (HKD125) & (HKD103) \\
\hline \multirow{2}{*}{$\begin{array}{c}\text { Yamagata-ken Oki } \\
\text { Earthquake } 2019\end{array}$} & Atsumi & Hijiori & Tsuruoka \\
\hline & (YMT004) & (YMT005) & (YMT003) \\
\hline
\end{tabular}
て算出する。詳細は文献 16)に示されていることから，本論文では割愛する。 付録 2 : 追加地震波

付表 1 に追加地震波の一覧を示す。全ての計測地震動には, $0.1 \mathrm{~Hz}$ ローパ スフィルターを用いた。また，計算時間刻みは，0.01s とした。付図 1 に鳥取 県西部地震 $2000 \mathrm{Niimi}$ 波, 新潟県中越沖地震 2007 Teradomari 波の加速度応答 スペクトル $(\mathrm{PGV}=0.50 \mathrm{~m} / \mathrm{s})$ を $\mathrm{E}$ l Centro 波と合わせて示す。

付録 $3: \eta=0.33,3.3$ の連層柱の断面設計例

表 1 の部材を有する 6,9 層 3 スパン骨組に連層柱曲げ剛性比 $\eta=0.33$ と 3.3
A. Table. 1 List of recorded ground motions

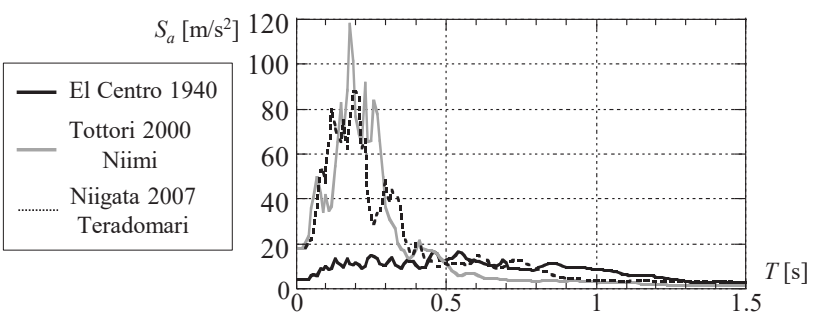

A.Fig.1 Pseudo acceleration response spectra $(h=0.05)$

A. Table 2 Demand on designing M.L.column

\begin{tabular}{|c|c|c|c|c|c|c|c|}
\hline \multirow{2}{*}{ frame } & \multirow{2}{*}{$\eta$} & \multirow{2}{*}{$\Sigma E_{C} I_{C 1}$} & $E_{M L} I_{M L}$ & \multicolumn{2}{|c|}{$M_{l \max } / M_{p C 1}(0.75 \mathrm{~m} / \mathrm{s})$} & \multicolumn{2}{|c|}{$V_{I \max }(\mathrm{kN})(0.75 \mathrm{~m} / \mathrm{s})$} \\
\cline { 5 - 8 } & & & (Required) & El Centro & Max & El Centro & Max \\
\hline \hline \multirow{2}{*}{6} & 3.3 & $2.83 \times 10^{6}$ & $5.60 \times 10^{7}$ & 1.86 & 7.46 & 970 & 3173 \\
\cline { 2 - 8 } & 0.33 & $2.83 \times 10^{6}$ & $5.60 \times 10^{6}$ & 0.68 & 1.19 & 523 & 965 \\
\hline \multirow{2}{*}{9} & 3.3 & $2.85 \times 10^{6}$ & $8.46 \times 10^{7}$ & 2.24 & 8.70 & 722 & 2851 \\
\cline { 2 - 8 } & 0.33 & $2.85 \times 10^{6}$ & $8.46 \times 10^{6}$ & 0.64 & 1.37 & 261 & 1109 \\
\hline
\end{tabular}

A. Table. 3 Sectional example and capacity of M.L.column (as RC wall)

\begin{tabular}{|c|c|c|c|c|c|c|c|}
\hline frame & $\eta$ & $\begin{array}{c}\text { M.L.column } \\
\text { section }\end{array}$ & rebar & shear reinf. & $E_{M L} I_{M L}$ & $M_{A l} / M_{p C 1}$ & $Q_{A S l}(\mathrm{kN})$ \\
\hline \hline \multirow{2}{*}{6} & 3.3 & $3800 \times 500$ & $54-\mathrm{D} 29^{(*)}$ & D13@75 & $5.93 \times 10^{7}$ & 8.03 & 3557 \\
\cline { 2 - 8 } & 0.33 & $2000 \times 350$ & $24-\mathrm{D} 29$ & D13@150 & $6.05 \times 10^{6}$ & 1.92 & 1054 \\
\hline \multirow{2}{*}{9} & 3.3 & $4100 \times 600$ & $56-\mathrm{D} 29^{(* 1)}$ & D13@100 & $8.94 \times 10^{7}$ & 8.92 & 3241 \\
\cline { 2 - 8 } & 0.33 & $2300 \times 350$ & 24-D29 & D13@150 & $9.21 \times 10^{6}$ & 2.27 & 1212 \\
\hline
\end{tabular}

(*1) 6-D29 are doubly arranged at both ends of wall.

$(* 2)$ rebar: SD345; shear reinforcement: SD390; $F c=36 \mathrm{~N} / \mathrm{mm}^{2}$ (*3) $M_{A l}$ is calculated considering the effect of prestress by PC of $7 \mathrm{~N} / \mathrm{mm}^{2}$.

の連層柱を付与する場合に必要な断面を算定する。ここでは連層柱として, 既往の文献 8)で実建築物の耐震改修で採用されたロッキング壁と名付けた PC によるプレストレスを導入した RC 壁を想定する。なお，既往の文献 8)の ロッキング壁は, $\eta=2$ 程度と推定される。

補表 2 に, 6, 9 層 3 スパン骨組に $\eta=0.33$ と 3.3 の連層柱を付与する場合に 必要な連層柱の曲げ剛性 $E_{M L} I_{M L}$ と, 連層柱に作用寸る曲げモーメント $M_{I \max }$ と せん断力 $V_{l \max }$ を示す。必要な $E_{M L} I_{M L}$ は層を構成する柱の曲げ剛性の単純和と 本文(8)式で算出される。 $M_{l \max }$ と $V_{l \max }$ は, 4.5 節図 14 に示した解析結果であ る。補表 2 には, $\mathrm{PGV}=0.75 \mathrm{~m} / \mathrm{s}$ とした地震動を用いた解析結果の内, El Centro 波と全地震動中の最大值を示している。

補表 3 に, 補表 2 に示す連層柱への要求值を満たす $\mathrm{RC}$ 壁の断面を示す。 $\mathrm{RC}$ 壁の断面は既往の文献 8)を参考に設定した。許容曲げモーメント $M_{A l}$ と短 期許容せん断力 $Q_{A S I}$ は鉄筋コンクリート構造計算規準・同解説 2018 より算出 した。補表 3 より， $\eta=0.33$ と 3.3 の曲げ剛性を満たすコンクリート断面を設 定した場合， RC 規準に基づいて配筋を調整することで，本論文で検討した全 地震動入力時に連層柱に作用する曲げモーメントとせん断力以上の許容曲げ モーメントと短期許容せん断力を有する連層柱を設定できる。 


\author{
Sachi FURUKAWA *1, Naoki TAMURA*2 and Yoshihiro KIMURA *3 \\ ${ }^{* 1}$ Assist. Prof., Graduate School of Eng., Tohoku University, Dr.Eng. \\ ${ }^{* 2}$ Grad. Student, Graduate School of Eng., Tohoku University, B.Eng. \\ ${ }^{* 3}$ Prof., Graduate School of Eng., Tohoku University, Dr.Eng.
}

According to current design practices of steel moment-resisting frames, formation of plastic hinges is unavoidable when the frames are supported by conventional column base systems, i.e., exposed-type and embedded-type column base systems, due to unequalized flexural moment demand on the top and base of the first story columns [1]. Kimura et.al [3] has proposed mid-story pin column base system to avoid columns from yielding and to realize formation of beam-yielding mechanism by applying pin connection between the upper steel column and the bottom RC column at the midpoints of the first story. Previous analytical study [3 7] indicated that the frames with the proposed column base system exhibits superior seismic behavior than those with conventional base column systems, mitigating probability of column yielding. However, it is also revealed the difficulty to realize beam yielding mechanism for frames with commonly adopted column-beam strength ratio of 1.4-1.8. Dual structural system is the system that the main structural frame resisting lateral force is backed up by secondary structural system. Previous studies [8 15] shows secondary structural systems, such as a force-demand spreading column [12] and rocking wall [14], sufficiently contribute to redistribution of the inelastic demand over the height of the frames.

In this paper, mechanical characteristics is examined about a steel moment-resisting frame with mid-story pin column base system upgraded by implementation of continuous column over the height of the frame. The continuous column is named as multi-layered leaning column (M. L. column), hereinafter. A theoretical formulation based on equilibrium equations between dual structural system (the main frame and M. L. column) is presented, in which those of the main frame is formulated by the previously presented modified D-value method [16]. Nonlinear static and timehistory analysis is implemented to validate the theoretical observations on the effect of M. L. column on the mechanical characteristics of the main frame (story drift concentration and flexural demand on structural components) and quantify the required flexural stiffness and strength of the M. L. column. Additional theoretical method is also presented to characterize the significant effect of high-order mode responses on flexural demand on the M.L. column based on modal decomposition method.

Static analysis of three-, six-, nine-story frame validates the theoretical formulation to sufficiently predict mechanical behavior of the frame with M. L. column. The flexural stiffness ratio of M. L. column $\eta$ is presented, where it is indicated that almost no advantage can be obtained with the M. L. column of $\eta<0.03$, while little further improvement can be expected with the M. L. column of $\eta>3.3$. With the M.L. column of $\eta=0.33$, about the half of the mitigation effect provided by a fully rigid M.L. column $(\eta=3.3)$ can be expected. Seismic time-history analysis shows that the maximum story drift concentration rate and flexural demands on the column of the main frame during earthquake excitation are well-predicted by the theoretical formulation with an external force regarding to Ai distribution, while the maximum flexural moment of the M.L. column exceeds the predicted value by 2.0 times. Theoretical formulation with proposed external force considering secondary mode response enhanced by seismic excitation successfully predicts the maximum flexural demand of the columns simulated by dynamic analysis of three to nine-stories frame with the M. L. column of $\eta=0.03$ to 3.3 . 